NBER WORKING PAPER SERIES

\title{
THE POSSIBLE UNEMPLOYMENT COST OF AVERAGE INFLATION BELOW A CREDIBLE TARGET
}

\author{
Lars E.O. Svensson \\ Working Paper 19442 \\ http://www.nber.org/papers/w19442 \\ NATIONAL BUREAU OF ECONOMIC RESEARCH \\ 1050 Massachusetts Avenue \\ Cambridge, MA 02138 \\ September 2013
}

I thank, without implication, George Akerlof, Björn Andersson, Meredith Beechey, Roberto Billi, Martina Björkman Nyqvist, David Domeij, Michael Dotsey, Karolina Ekholm, Tore Ellingsen, Neil Ericson, Ante Farm, Jon Faust, Martin Flodén, Jeffrey Fuhrer, Jordi Galí, Stefan Gerlach, Paolo Giordani, Nils Gottfries, Jesper Hansson, Kerstin Hallsten, Laura Hartman, Per Jansson, Anil Kashyap, Paul Klein, Vincent Koen, Anna Larsson, Stefan Laséen, Eric Leeper, Lars Ljungqvist, Assar Lindbeck, Jesper Lindé, Henrik Lundvall, Stefan Mellin, Erik Meyersson, Mats Morin, Christina Nyman, Pär Österholm, Stefan Palmqvist, Torsten Persson, Ola Pettersson, Ricardo Reis, Irma Rosenberg, Glenn Rudebusch, Ulf Söderström, Ingvar Strid, Anders Vredin, Karl Walentin, Michael Woodford, Janet Yellen, the editor and two referees, and participants in seminars at the Federal Reserve Board, the IIES at Stockholm University, the National Institute of Economic Research, the NBER Monetary Economics Program meeting at the Chicago Fed, the Riksbank, and the Stockholm School of Economics for helpful comments and discussions. Extensive discussions with Bertil Holmlund have been particularly helpful. I thank Christina Lönnblad for editorial assistance. The views expressed herein are those of the author and do not necessarily reflect the views of the National Bureau of Economic Research.

NBER working papers are circulated for discussion and comment purposes. They have not been peerreviewed or been subject to the review by the NBER Board of Directors that accompanies official NBER publications.

(C) 2013 by Lars E.O. Svensson. All rights reserved. Short sections of text, not to exceed two paragraphs, may be quoted without explicit permission provided that full credit, including $(\mathrm{C}$ notice, is given to the source. 
The Possible Unemployment Cost of Average Inflation below a Credible Target

Lars E.O. Svensson

NBER Working Paper No. 19442

September 2013ா5 HMUHAS SU⿴囗十丁

JEL No. E24,E31,E52,E58

\begin{abstract}
$\underline{\text { ABSTRACT }}$
If inflation expectations become firmly anchored at the inflation target even when average inflation deviates from the target, the long-run Phillips curve becomes non-vertical. During 1997-2011, average inflation expectations in Sweden have been close to the inflation target of 2 percent, whereas average inflation has fallen short of the target by 0.6 percentage points. The estimates reported suggest that the slope of the long-run Phillips curve is about 0.75 . Then the average unemployment rate has been about 0.8 percentage points higher than if average inflation had been on target. This is a large unemployment cost of undershooting the inflation target.
\end{abstract}

Lars E.O. Svensson

SIFR - The Institute for Financial Research

Swedish House of Finance

Stockholm School of Economics

Drottninggatan 98

SE-11160 Stockholm

Sweden

and Stockholm University

and also NBER

lars.svensson@iies.su.se 
In 1993, the Riksbank announced an official target for annual CPI inflation of 2 percent, to apply from 1995. By 1997, the new inflation-targeting regime had been established, in the sense that the inflation target was credible (inflation expectations were in line with the target), the repo rate (the Riksbank's policy rate) had been lowered to a normal level, and the Riksbank had had a few years to learn how to conduct inflation targeting. Over the next 15 years, 1997-2011, average CPI inflation has equaled 1.4 percent and has thus fallen short of the target by 0.6 percentage points. In contrast, in Australia, Canada, and the U.K., which have had a fixed inflation target as long as Sweden, average inflation has been on or very close to the target. Has this undershooting of the inflation target in Sweden had any costs in terms of higher average unemployment? This depends on whether the long-run Phillips curve in Sweden is vertical or not. During 1997-2011, inflation expectations in Sweden have been anchored to the inflation target, in the sense that average inflation expectations have been close to the target. The inflation target has thus been credible. If inflation expectations are anchored to the target also when average inflation deviates from the target, the long-run Phillips curve is no longer vertical but downward-sloping. Then, average inflation below the credible target means that average unemployment is higher than it would have been if average inflation had been on target. The estimates reported below suggest that the average unemployment rate has been 0.8 percentage points higher during 1997-2011. This is a large unemployment cost of undershooting the inflation target. Some simple robustness tests indicate that the estimate of the unemployment cost is rather robust.

It is well known that inflation expectations have become anchored in many countries. It has been noted that this may explain why inflation has become less persistent, as discussed by Williams (2006). Fuhrer (2011) notes that inflation expectations for the U.S. have been anchored from 2000 onwards and estimates a downward-sloping long-run Phillips curve. IMF (2013) notes that longer-term inflation expectations have become more firmly anchored in many countries and that Phillips curves appear to have become flatter, in that inflation has become less responsive to changes in economic slack. What is new in my paper is the empirical evidence for Sweden that anchored inflation expectations have led to a downward-sloping long-run Phillips curve, that average inflation below a credible inflation target has brought higher average unemployment than if average inflation had been kept on target, and that this average unemployment cost for Sweden is substantial. Furthermore, the Swedish case stands out - central banks in other countries that have had inflation targets for as long as Sweden have avoided such unemployment costs by keeping long-term average inflation on or close to the target.

The paper is outlined as follows: Section 1 discusses inflation and inflation expectations in Sweden since the introduction of the inflation target. Section 2 makes a comparison with the inflation outcome in Australia, Canada, and the U.K., which have had a fixed inflation target for as long a period of time as Sweden, and with the inflation outcome in the euro area and the United States. Section 3 discusses non-rational inflation expectations and wage-setting in Sweden. Section 4 estimates a short- and a long-run Phillips curve for Sweden. Section 5 discusses the unemployment cost of average inflation below the inflation target. Section 6 conducts some robustness tests. Section 7 estimates a long-run Phillips curve for the U.S. for 2000-2011 and shows that it is non-vertical and downward-sloping, something that Fuhrer (2011) has also noted. Section 8 does the same for Canada for 1997-2012. Since average inflation has been equal or close to a widely held perception of an unofficial Federal Reserve inflation target of about 2 percent and an official Bank of Canada inflation target of 2 percent, there is no unemployment cost of average inflation below target in these countries. Section 9 provides some conclusions. Appendices A1-A5 provide some details. 


\section{Average inflation below and average inflation expectations on the target}

Figure 1 shows quarterly data from 1996 through 2011 of real-time annual CPI inflation, inflation expectations from the survey the Riksbank has commissioned from TNS Sifo Prospera of annual CPI inflation one and two years ahead, and the unemployment rate (15-74 age group). Throughout this paper, I assume that the Prospera survey is representative of private-sector inflation expectations in Sweden. ${ }^{1}$

Figure 1. Annual CPI inflation, CPI inflation expectations one and two years ahead (Prospera, all interviewees), and unemployment (15-74 age group).

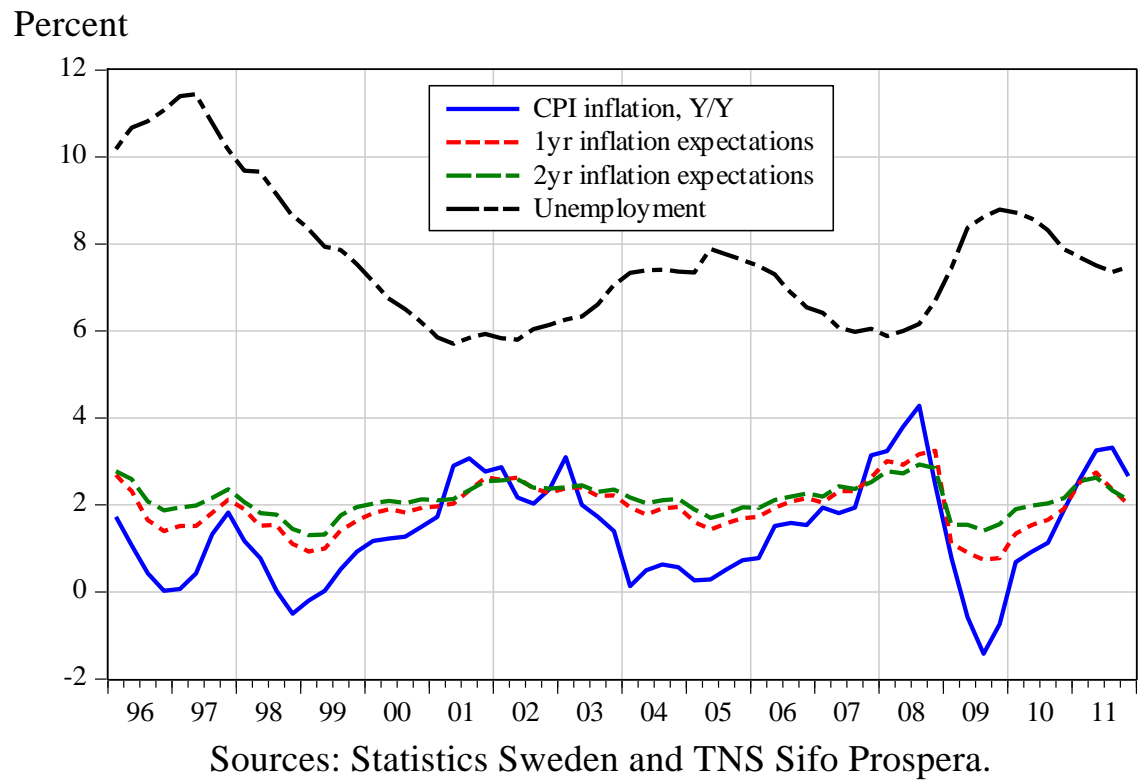

During the period 1997-2011, average real-time CPI inflation has equaled 1.43 percent, thus undershooting the target of 2 percent by about 0.6 percentage points. Average revised CPI inflation was even lower, 1.31 percent during the same period. ${ }^{2}$

It is not quite obvious whether real-time or revised inflation data is most appropriate for the present study. One may argue that it was real-time inflation data that were published and perceived as relevant at the time, and that it was these data that influenced expectations, wage setting, employment and other economic decisions. On the other hand, one might argue that uncovering the relations between unemployment and inflation calls for the most accurate, and thus revised, data to be used. But without a more detailed and precise model of agents' behavior, information, and decisions, it is not clear whether "true" data is more relevant than "perceived" data in this case. Furthermore, as shown in the robustness tests below, the slope of the long-run Phillips curve is not sensitive to whether real-time or revised data are used. Thus, the main difference is that with real-time inflation instead of revised, average inflation undershoots the inflation target by about 0.6 percentage points instead of about 0.7 ,

\footnotetext{
${ }^{1}$ In 1995, the Riksbank commissioned Prospera Research (now TNS Sifo Prospera) to conduct a survey of the expectations of inflation and wage increases of a panel of labor market organizations, purchase managers, and money-market players. The first report was published in November 1995. Initially the survey was to be published three times a year, but from 1996 the survey was conducted quarterly. Later the survey was expanded to include expectations of future GDP growth and repo rates and, for money-market players, also expectations of future five-year government bond rates and USD and EUR exchange rates.

${ }^{2}$ As is explained in Sveriges Riksbank (2004), before 2005, CPI inflation was measured by Statistics Sweden not as the annual percentage increase in the CPI but with a method that excluded substitution effects on the composition of the consumption basket, making measured inflation on average 0.2 percentage points higher. From 2005, CPI inflation is measured as the annual percentage change in the CPI.
} 
and the average unemployment cost is about 0.8 percentage points instead of about 0.9 . In the contentious Swedish debate about the Riksbank's deviation from its inflation target and the associated average unemployment cost, using real-time data has the advantage that it avoids possibly exaggerating the target deviation and associated unemployment cost. The deviation and cost are both large also with the real-time data. Given this, I use the real-time data.

As seen in figure 1, one- and two-year-ahead inflation expectations collected by Prospera are close to 2 percent from the second half of 1996 onwards. A different series of inflation expectations with earlier observations, collected by Aragon Securities Fondkommission and referring to expectations of money-market participants only, is shown in figure 2, together with annual CPI inflation, unemployment, and the repo rate (the Riksbank's policy rate). ${ }^{3}$ The expectations shown are average expectations for the next two years and the next five years. We see that the credibility of the inflation target was quite low after its announcement in January 1993. The expected average inflation for the next five years was about 4 percent through the first half of 1995. Only toward the end of 1996 is the expected average inflation for the next two and the next five years close to 2 percent.

Figure 2. Annual CPI inflation, expectations of average CPI inflation the next 2 and 5 years (Aragon), unemployment (15-74 age group), and the repo rate

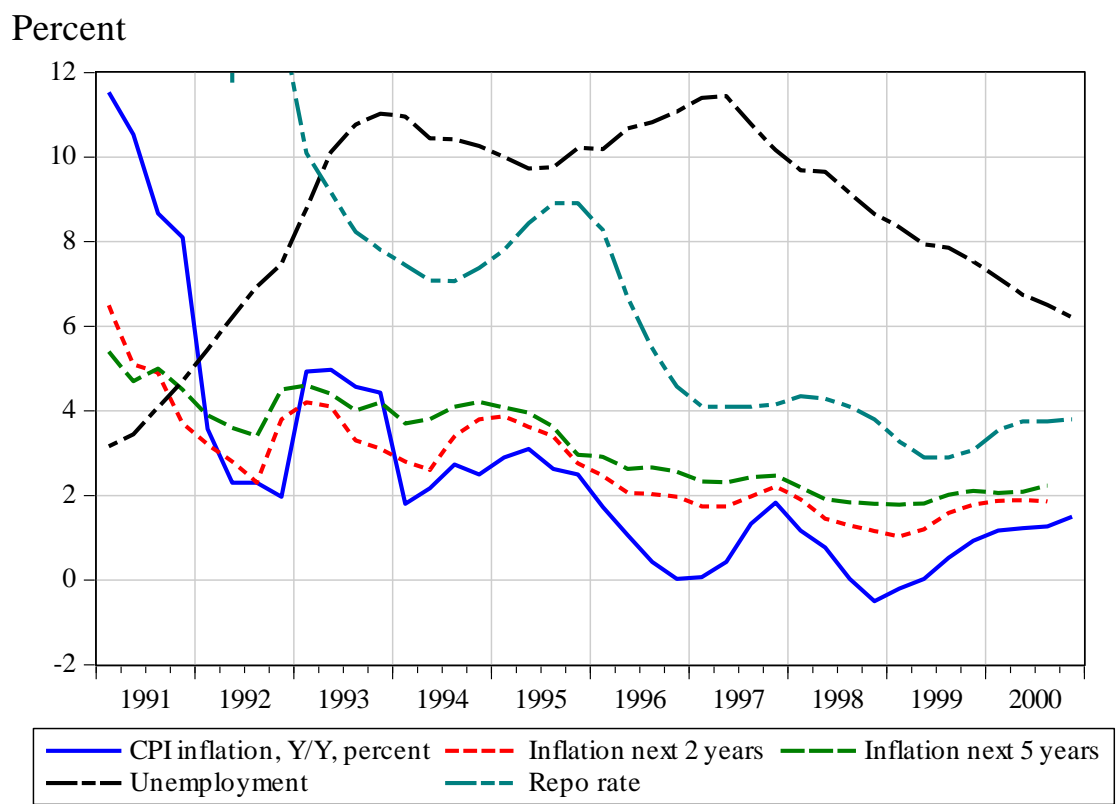

Source: Statistics Sweden, Aragon Securities Fondkommission, Stockholm and Sveriges Riksbank.

The high inflation expectations before 1997 mean that, everything else equal, tighter monetary policy with higher unemployment was needed to bring inflation close to the target. From 1997 onwards, inflation expectations were close to 2 percent, and this reason for a tighter policy no longer applied. Furthermore, figure 2 shows that the repo rate by early 1997 had been lowered to a normal level, 4 percent. Moreover, by 1997, the Riksbank had had a few years to learn how to conduct monetary policy under inflation targeting. ${ }^{4}$ Thus, by 1997, the new inflation-targeting regime had established itself. Therefore, it is appropriate to scrutinize monetary policy from 1997 and onwards. ${ }^{5}$

\footnotetext{
${ }^{3}$ The Aragon series was discontinued in 2000.

${ }^{4}$ The paper Svensson (1997) about the principles of inflation targeting was written in 1996 when I was an advisor to the Riksbank and was much stimulated by several meetings with Riksbank staff and management in
} 
Thus, both the Prospera and Aragon series indicate that inflation expectations were anchored to the inflation target from 1997, but not before, in the sense that the average inflation expectations were close to the target. Figure 3 shows five-year moving averages of inflation expectations one and two years ahead and real-time CPI inflation.

Figure 3. CPI inflation expectations one and two years ahead (all interviewees) and CPI inflation, five-year trailing moving averages.

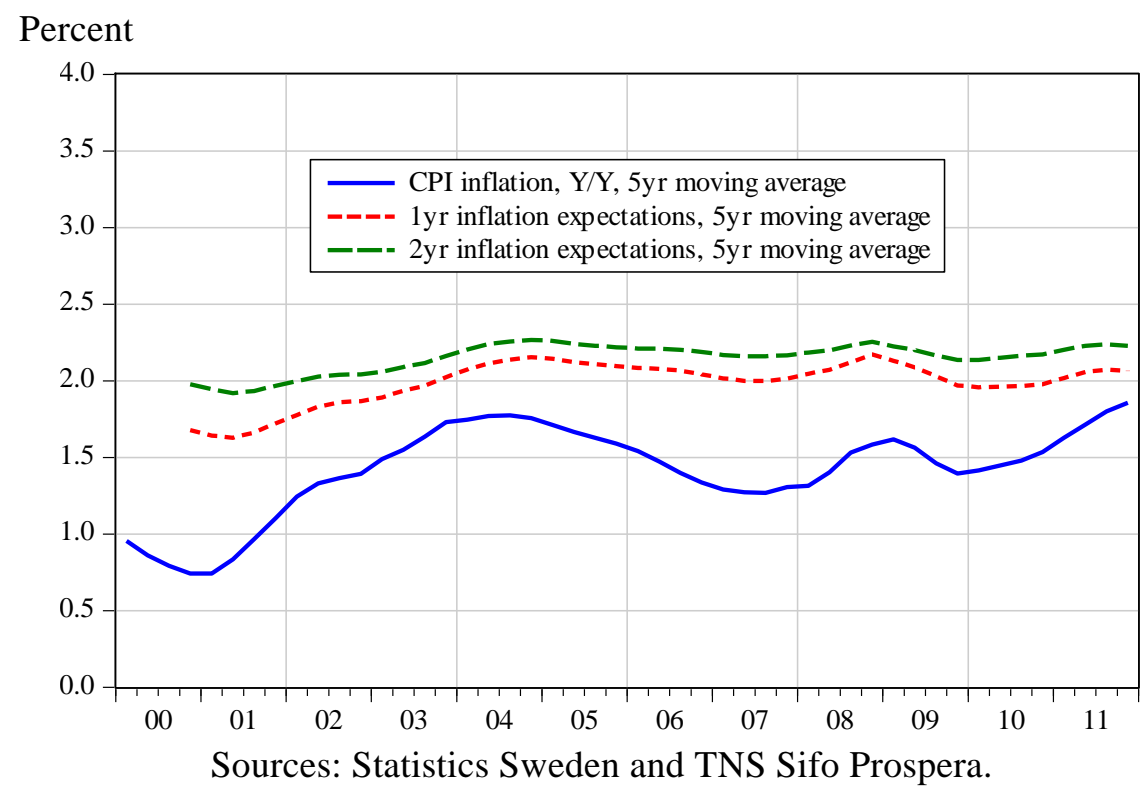

For the period 1997-2011, the average inflation expectations one and two years ahead are 1.94 and 2.13 percent, respectively. My starting point is therefore that during 1997-2011, the inflation expectations have on average equaled the target of 2 percent and that average CPI inflation has fallen short of the target by 0.6 percentage points. Before further examining the consequences of this, let me compare average inflation in Sweden with average inflation in other countries that have had a fixed inflation target as long as Sweden.

\section{Inflation in other countries that have had a fixed inflation target as long as Sweden}

Naturally, one cannot expect average inflation to have been exactly on target over a period of about 15 years. To get an idea of what is possible, however, we can compare average inflation in Sweden to average inflation in other countries that have had a fixed inflation target as long as Sweden, that is, since the early 1990s. Those countries are Australia, Canada, and the U.K. The first country to introduce explicit inflation targeting was New Zealand in 1990, but its inflation target has not been

which the principles of inflation targeting were being debated and developed. These principles were, as far as I can remember, gradually applied from 1997 and onwards.

${ }^{5}$ Andersson, Palmqvist, and Österholm (2012) discuss the inflation target attainment of the Riksbank for the period 1995-2011 and note that average real-time CPI inflation was 1.5 percent during this period (rather than 1.4 for 1997-2011). They do not discuss the consequences for average unemployment of undershooting the target. In order to discuss the consequences for average unemployment, it would be misleading to include the period 1995-1997 in the sample, since inflation expectations exceeded the inflation target before 1997, as discussed above. If the long-run Phillips curve is nevertheless estimated for the longer sample 1995-2011, the estimated slope is flatter than the benchmark estimated for 1997-2001 below, and the excess average unemployment ends up being larger than the benchmark, even if the smaller average undershooting of 0.5 percentage points is used. 
fixed but has been adjusted upwards twice, making the comparison less straightforward. Therefore, it is not included in the comparison. It is also reasonable to exempt the very first years of the new inflation-targeting regime for Sweden and other countries, giving the regime some time to become established and the central bank to gain some experience. I therefore compare average inflation over the same period as for Sweden, 1997-2011.

The comparison is summarized in table 1. Australia has had an inflation target since mid-1993. The target is to achieve an average CPI inflation rate of between 2 and 3 percent over the business cycle. As shown in the table, average CPI inflation over 1997-2011 has been 2.7 percent, exceeding the midpoint of the target range by 0.2 percentage points. Canada has had an inflation target since 1991, which is 2 percent for CPI inflation from the end of 1995. Average CPI inflation over 1997-2011 is 2.0 percent.

Table 1. Inflation target, average inflation, and average deviation from target for Australia, Canada, Sweden, and the U.K.; implicit inflation target and average inflation for the euro area and the U.S

\begin{tabular}{cccccc}
\hline Country & Target & Index & Period & Average & Average less target \\
\hline Australia & $2-3$ & CPI & $1997-2011$ & 2.7 & 0.2 \\
Canada & 2 & CPI & $1997-2011$ & 2.0 & 0.0 \\
Sweden & $\mathbf{2}$ & CPI & $1997-2011$ & $\mathbf{1 . 4}$ & $\mathbf{- 0 . 6}$ \\
Sweden & $\mathbf{2}$ & CPI & $1997-2007$ & $\mathbf{1 . 3}$ & $\mathbf{- 0 . 7}$ \\
U.K. & $2.5(1992-2003)$ & RPIX & $1997-2003$ & 2.4 & -0.1 \\
& $2(2004-)$ & CPI & $2004-2007$ & 2.0 & 0.0 \\
& $2(2004-)$ & CPI & $2008-2011$ & 3.4 & 1.4 \\
Euro area & $(<2)$ & HICP & $2000-2011$ & 2.1 & \\
U.S. & $(\leq 2)$ & Core CPI & $2000-2011$ & 2.0 & \\
& $(\leq 2)$ & Core PCE & $2000-2011$ & 1.9 & \\
\hline
\end{tabular}

Source: Reuters Ecowin and Statistics Sweden.

The U.K. has had an inflation target from the end of 1992, which was, however, somewhat modified at the end of 2003. Up to the end of 2003, the U.K. inflation target was 2.5 percent for the RPIX price index. ${ }^{6}$ Average RPIX inflation over 1997-2003 was 2.5 percent. Since 2004 the inflation target has been 2 percent for the CPI price index. I do not regard this as any significant change in the inflation target, since CPI inflation has on average been about 0.75 percentage points lower than RPIX inflation. ${ }^{7}$ The average CPI inflation rate over 2004-2007 was 2.0 percent, while the average over the crisis years 2008-2011 was higher, at 3.4 percent. However, given the high unemployment rate in the United Kingdom during the crisis, optimal policy implies that inflation should overshoot the target. As previously noted, one might argue that the crisis years are special and could be excluded. If they are excluded for Sweden, the average CPI inflation rate over 1997-2007 was 1.3 percent, 0.7 percentage points below the target.

How have things turned out for the large economies, the euro area and the United States? The euro area has had a target for inflation, although during a shorter period than the countries mentioned earlier. The target is that HICP inflation should be below but close to 2 percent. The average HICP inflation rate in the euro area in the period 2000-2011 was 2.1 percent. The United States, on the other

\footnotetext{
${ }^{6}$ In the period 1992-1996, the target was expressed as 2.5 percent or lower in terms of the RPIX price index.

${ }^{7}$ The CPI price index in the U.K. is the same as the HICP price index. Since 1993, average CPI inflation has been 0.75 percentage points lower than average RPIX inflation.
} 
hand, did not have an official inflation target until the Federal Reserve announced a target of 2 percent for PCE inflation in January 2012. ${ }^{8}$ However, a widely held perception is that even prior to this, the Federal Reserve had an unofficial target for core inflation of about 2 percent (Fuhrer 2011, p. 5). The average for core CPI inflation in the United States in the period 2000-2011 was 2.0 percent and for core PCE inflation 1.9 percent.

In this comparison, Sweden stands out, with average CPI inflation having significantly undershot the inflation target, whereas for the other countries, average inflation has been quite close to the target or slightly overshot the target (except the U.K. for 2008-2011 when inflation substantially overshot the target).

\section{Non-rational expectations and wage-setting in Sweden}

The average inflation expectations reported in figure 1 are economically and statistically significantly above average inflation. ${ }^{9}$ Jonsson and Österholm (2012) show that they do not pass standard rationality test. Perhaps they are "near-rational" as in Akerlof, Dickens, and Perry (2000) (ADP).

\subsection{Near-rational inflation expectations at the inflation target of 2 percent rather than at an inflation of zero percent}

In ADP, near-rational behavior means that, when inflation does not deviate too much from zero, a significant fraction of the private sector neglects inflation and behaves as if it would equal zero. When inflation rises sufficiently above zero, an increasing fraction of the private sector becomes rational and has rational expectations. The result is a long-run Phillips curve that is vertical and equal to the longrun natural rate for high inflation rates, has a hump to the left for low positive inflation rates, and equals the long-run natural rate for zero inflation. ${ }^{10}$

In the present context, near-rational behavior would mean that, when average inflation does not deviate too much from the inflation target of 2 percent, a significant fraction of the private sector neglects that deviation and behaves as if average inflation were to equal the inflation target. A possible explanation is that this fraction of the private sector may have been more influenced by the Riksbank's communication of the inflation target of 2 percent than by actual average inflation. Thus, whereas near-rational behavior in ADP is with reference to zero inflation, here it would be with reference to the inflation target of 2 percent.

The situation may be illustrated as in figure 4. The long-run Phillips curve is shaped as in ADP and has a hump to the left for average inflation above 2 percent. It is extended for average inflation below 2 percent. It may have a hump to the right. Then, for very low or negative average inflation rates, it would bend back towards the long-run natural rate. On the other hand, downward nominal wage rigidity might prevent it from bending back. The Swedish data during the sample of 1997 are roughly within the ellipse. Given the limited range of the data, it will not be possible to estimate its shape for very low or negative average inflation rates.

\footnotetext{
${ }^{8}$ PCE inflation is inflation measured with the personal consumption expenditure deflator.

${ }^{9}$ A regression 1997-2011 of one-year-ahead inflation expectations less CPI inflation on a constant results in the constant 0.51 and a Newey-West standard error (lag 4) of 0.16 .

${ }^{10}$ Lundborg and Sacklén have estimated the ADP long-run Phillips curve on Swedish data. Bryan and Palmqvist (2010) test some particular hypotheses that follow from the ADP assumptions.
} 
Figure 4. Modified long-run Phillips curve of Akerlof, Dickens, and Perry Figure 1. A Hypothetical Long-Run Phillips Curve

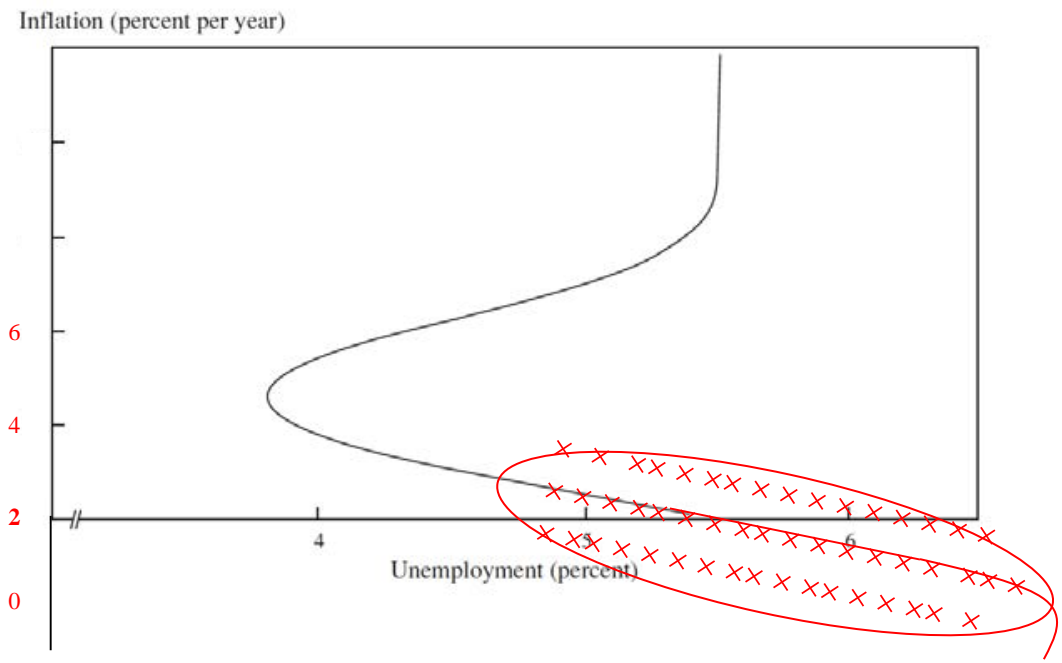

\subsection{Wage setting in Sweden influenced by the Riksbank's inflation target rather than by actual inflation}

There is evidence that the Riksbank's inflation target of 2 percent rather than the recent actual inflation rate is what influences central wage negotiations and overall wage setting in Sweden. Central wage negotiations are important for wage-setting in Sweden. The so-called Industrial Cooperation and Negotiation Agreement (ICNA) has been in force since 1997 and has become an important institution in Swedish wage formation. The ICNA came into being after the round of collective bargaining in 1995 when the social partners failed to co-ordinate their negotiations. Co-ordination has improved since the ICNA was signed and collective wage agreements in the manufacturing industry have become the norm for other contractual areas. (National Institute of Economic Research 2012, Sveriges Riksbank 2011, Gottfries 2012.)

In particular, central wage negations in Sweden start from an assumption that the Riksbank will attain its inflation target and that CPI inflation will be 2 percent, regardless of what actual inflation is or has been. This is can be seen in documents about the principles of wage negotiations from the Swedish Trade Union Confederation (Morin 2009):

During the years 1995-2008 the CPI has on average increased by 1.4 percent... That the price increase has fallen short of the inflation target should not be the starting point for a future assessment. Instead, the reference point for wage formation should be that the Riksbank will attain the inflation target of 2 percent... (Morin 2009, p. 15, own translation from Swedish)

More recently, the Industrial Trade Unions expressed similar principles in their wage-settlement policy platforms before the wage-negotiations in 2011-2012 and 2012-2013 (Facken inom industrin 2011, 2012).

[The Riksbank's inflation target] is an important starting point for the labor-market parties when they negotiate about new wages. ...

In negotiations about new wage settlements, the parties should act as if the Riksbank will attain its inflation target... 
Inflation sometimes displays large fluctuations around the Riksbank's inflation target... Should the labor market parties when assessing the room for wage increases try to take such temporary fluctuations into account, wage formation would become very unstable.

While acting as if the Riksbank will attain its inflation target, the parties contribute to inflation expectations around 2 percent. ... (Facken inom industrin 2011, p. 6-7, own translation from Swedish)

Thus, these quotations indicate that central wage negotiations in Sweden are conducted with inflation expectations equal to 2 percent, regardless of the fact that average inflation has fallen short of 2 percent, and regardless of whether actual inflation deviates from the Riksbank's inflation target at the time of the negotiations. Furthermore, those who have the power in the trade unions are usually more senior workers, "insiders," with relatively safe jobs, who do not suffer the loss of higher unemployment but rather tend to gain from higher real wages, when inflation falls short of 2 percent (Gottfries 2012, Lindbeck and Snower 2001). The employer side in the central wage negotiations naturally has an incentive to resist wage increases in line with the inflation target and rather have those be guided by actual inflation, when actual inflation tends to be lower than the target. Although I have inquired with officials in the employers' organizations, I have nevertheless been unable to find any quotations or statements indicating opposition to the inflation target as a guideline for wage setting. ${ }^{11}$

Suppose that nominal wages are set in negotiations a year in advance to achieve a particular target real wage next year at the price level expected for that year. If the inflation expectations equal the inflation target, the price level expected for next year is the current price level increased by the inflation target. This together with the target real wage then determines the level of nominal wages set for next year. If actual inflation over the coming year then falls short of the inflation target, the price level next year will be lower than anticipated, and the real wage will be higher than the target real wage. This will lead to lower employment and higher unemployment. See appendix A1 for details. ${ }^{12}$

\footnotetext{
${ }^{11}$ Bergström and Boije (2005) (at the time Deputy Governor of the Riksbank and Advisor at the Riksbank, respectively) discuss criticism at the time against the Riksbank that inflation had fallen short of the target and that this might have caused high unemployment during the period 1995-2005. They note and discuss reasons why average inflation has fallen short of the inflation target and unemployment has been high. They note that inflation expectations during 1994-1995 were far above the target, which required a high policy rate and high unemployment to reach the inflation target. It is understood although not emphasized that inflation expectations were later close to the target. They note that if inflation expectations adjust to average inflation, the long-run Phillips curve will be vertical. They mention the "wage norm”, that wage setting is guided by the Riksbank's inflation target and labor productivity (the Industrial Cooperation and Negotiation Agreement discussed above). They criticize Akerlof, Dickens and Perry (2000) and argue that a credible inflation target rather than zero inflation would be the natural starting point for wage negotiations. Thus they observe and discuss that inflation expectations and wage setting have been anchored at the inflation target whereas average inflation has fallen short of the target. However, they do not raise the possibility that this would imply that the long-run Phillips curve would no longer be vertical but downward-sloping and that average inflation below the target would then lead to higher average unemployment.

${ }^{12}$ Flodén (2012) notes that firms’ one-year inflation expectations collected and published by the National Institute of Economic Research (NIER) do not, on average, deviate from actual inflation and that rationality of those inflation expectations cannot be rejected. However, the statements from the Swedish Trade Union Confederation and the Industrial Trade Unions noted above, the fact that the TNS Sifo Prospera report inflation expectations of labor market organizations (both for employees and employers) similar to those of all interviewees reported here, and the importance for wage setting of central wage negotiations after the introduction of the Industrial Cooperation and Negotiation Agreement in 1997 together indicate that inflation expectations in line with the inflation target are more important than the NIER's firm inflation expectations in affecting wage setting in Sweden.
} 


\section{The long-run Phillips curve has become downward-sloping}

If inflation expectations are anchored on the target in the sense that average inflation expectations equal the target even though average inflation deviates from the target, the long-run expectationsaugmented Phillips curve is no longer vertical but downward-sloping. ${ }^{13}$ For illustrative purposes, consider the simplest expectations-augmented Phillips curve,

$$
\pi_{t}=\pi_{t}^{e}-\gamma\left(u_{t}-u^{*}\right)+\varepsilon_{t},
$$

where $\pi_{t}$ denotes inflation in quarter $t ; \pi_{t}^{e}$ denotes inflation expectations; $u_{t}$ denotes the unemployment rate; $u *$ denotes the natural rate; $\varepsilon_{t}$ denotes a shock with an unconditional mean equal to zero, $\mathrm{E}\left[\varepsilon_{t}\right]=0$; and $\gamma$ is a positive constant. For a New Keynesian Phillips curve, $\pi_{t}^{e}$ is the expectation in period $t$ of inflation in period $t+1$; for a New Classical Phillips curve, $\pi_{t}^{e}$ is the expectation in period $t-1$ of inflation in period $t$. Taking the unconditional mean of the Phillips curve (1) then results in the long-run relation between inflation, inflation expectations, and unemployment,

$$
\pi=\pi^{e}-\gamma\left(u-u^{*}\right),
$$

where $\pi=\mathrm{E}\left[\pi_{t}\right], \pi^{e}=\mathrm{E}\left[\pi_{t}^{e}\right]$, and $u=\mathrm{E}\left[u_{t}\right]$ denote the unconditional means of inflation, inflation expectations and the unemployment rate. Under rational expectations, the unconditional mean of inflation and inflation expectations are equal,

$$
\pi=\pi^{e},
$$

so from (2) and (3) it follows that the unconditional mean of the unemployment rate and the natural rate are equal,

$$
u=u^{*} .
$$

Then, the long-run Phillips curve is vertical, the unconditional mean of the unemployment rate is independent of the unconditional mean of inflation, and there is no long-run tradeoff between inflation and unemployment.

However, if the unconditional mean of inflation expectations equals the inflation target, $\pi^{*}$, regardless of the unconditional mean of inflation, the long-run Phillips curve will be

$$
\pi=\pi^{*}-\gamma\left(u-u^{*}\right)
$$

The long-run Phillips curve is then downward-sloping with (negative) slope $\gamma$, and there is a long-run tradeoff between inflation and unemployment. When the average inflation expectations equal the inflation target, average inflation below the target will imply average unemployment above the natural rate. $^{14}$

With inflation expectations stuck at the inflation target, the precise steady-state equilibria that result are determined by the aggregate-demand relation in the economy and the central bank's policy rule, as explained in detail in appendix A3.

\footnotetext{
${ }^{13}$ The anchoring of U.S. inflation expectations to 2 percent from 2000 onwards and the resulting downwardsloping U.S. Phillips curve have been noted by Fuhrer (2011).

${ }^{14}$ This is true if "average" refers to the unconditional mean. If "average" refers to a sample average for a particular sample, it is true if the sample average of the shocks in (1) is zero. If the sample mean of the shocks is not zero, average inflation below the target implies that average unemployment is higher than what it would have been with the same shocks if average inflation had been equal to the target. See appendix A2 for details.
} 


\subsection{An estimated short-run Phillips curve}

In order to estimate a long-run inflation Phillips curve, I first estimate a short-run Phillips curve. Then, I take the unconditional mean of the short-run Phillips curve to get the long-run Phillips curve. I use the quarterly real-time seasonally adjusted CPI inflation at an annual rate as the dependent variable. It is shown in figure $5 .^{15} 16$

Figure 5. CPI inflation, annual and quarterly seasonally adjusted at an annual rate

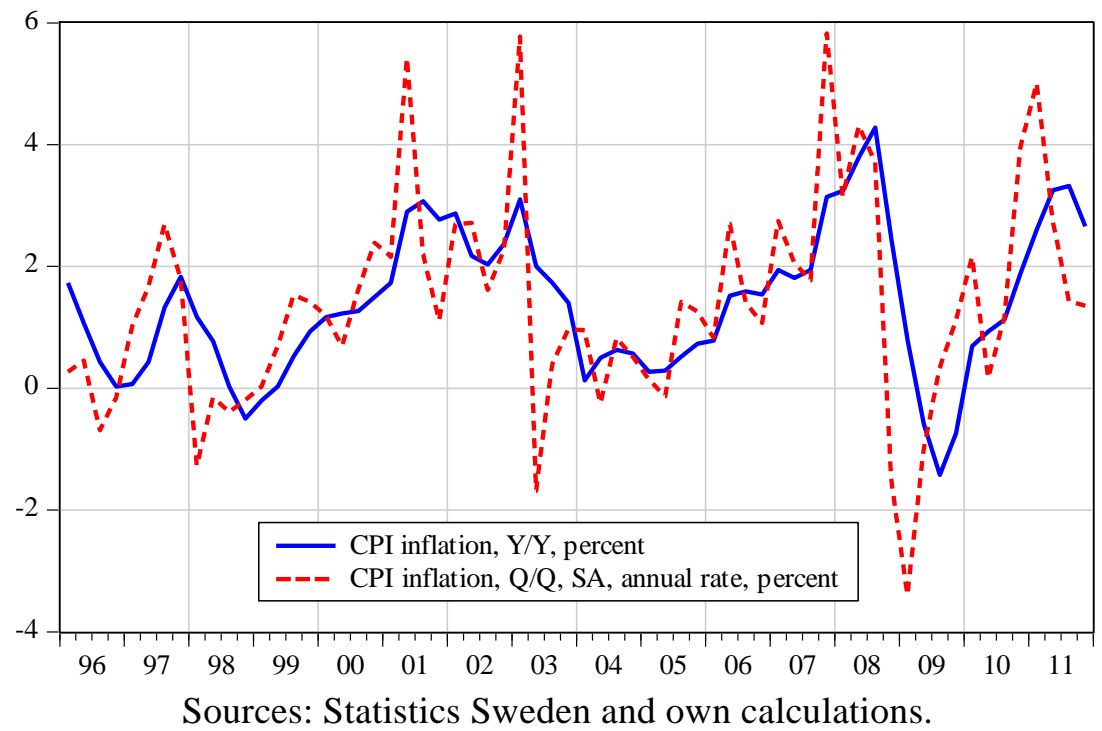

Since inflation expectations by figure 1 are so well anchored at the target and vary so little, my main hypothesis is that the short-run Phillips curve to be estimated can be written in the general form

$$
\alpha(\mathrm{L}) \pi_{t}=\beta(\mathrm{L}) u_{t}+\varepsilon_{t},
$$

where $\alpha(\mathrm{L})$ and $\beta(\mathrm{L})$ are lag polynomials, but where inflation expectations do not enter as a separate explanatory variable. Separately, I will test below whether inflation expectations can be excluded. The error term $\varepsilon_{t}$ is assumed to have mean zero and to be uncorrelated with the current and lagged unemployment rates and lagged inflation. That is, unemployment is here assumed to be predetermined one quarter; alternative hypotheses are examined in robustness tests below. In line with, for instance, Rudebusch and Svensson (1999) and Stock and Watson (2010), I allow lags of inflation and unemployment in the short-run Phillips curve and prefer to let the data decide whether they are needed to describe the short-run dynamics with well-behaved error terms.

The result of estimating (6) with OLS for the sample 1997Q4-2011Q4 is shown in table 2 (standard errors within parentheses, and p-values within brackets). Column (1) is the benchmark specification, which fits the data well. There, the explanatory variables are the change in the unemployment and lagged unemployment. Their coefficients are highly significant. Wald tests (not shown) do not reject that coefficients of more lags of unemployment and the coefficients of lags of inflation are zero. Serially uncorrelated error terms cannot be rejected at the 5 percent confidence level.

\footnotetext{
${ }^{15}$ The seasonal adjustment of the quarterly inflation is done with EViews and Census X12, additive.

${ }^{16}$ A previous version of the paper estimated a short-run Phillips curve with annual inflation as the dependent variable. Using annual inflation means using overlapping data, which introduces serial correlation in error terms and other econometric complications. Using overlapping data hardly has any advantages according to Harri and Brorsen (2009) compared to using underlying non-overlapping data. In the present case, using quarterly inflation leads to a simpler short-run Phillips curve and is in line with other studies of the Phillips curve. The estimated slope of the long-run Phillips curve is about the same regardless of whether quarterly or annual inflation is used.
} 
Table 2. Estimates of the short-run Phillips curve, 1997Q4-2011Q4

\begin{tabular}{|c|c|c|c|c|c|}
\hline & (1) & (2) & (3) & (4) & (5) \\
\hline Constant & $\begin{array}{c}7.192 \\
(\mathbf{1 . 3 6 0}) \\
{[0.0000]}\end{array}$ & $\begin{array}{c}8.230 \\
(1.771) \\
{[0.0000]}\end{array}$ & $\begin{array}{c}8.758 \\
(2.267) \\
{[0.0003]}\end{array}$ & $\begin{array}{c}6.638 \\
(1.220) \\
{[0.0000]}\end{array}$ & $\begin{array}{c}5.227 \\
(1.393) \\
{[0.0004]}\end{array}$ \\
\hline$u_{t}-u_{t-1}$ & $\begin{array}{c}-2.700 \\
(0.723) \\
{[0.0005]}\end{array}$ & $\begin{array}{c}-2.156 \\
(0.936) \\
{[0.0253]}\end{array}$ & $\begin{array}{c}-2.678 \\
(0.725) \\
{[0.0005]}\end{array}$ & & \\
\hline$u_{t-1}$ & $\begin{array}{c}\mathbf{- 0 . 8 0 7} \\
(\mathbf{0 . 1 8 6}) \\
{[0.0001]}\end{array}$ & $\begin{array}{c}-0.826 \\
(0.188) \\
{[0.0001]}\end{array}$ & $\begin{array}{c}-0.917 \\
(0.226) \\
{[0.0002]}\end{array}$ & & $\begin{array}{c}-0.516 \\
(0.177) \\
{[0.0050]}\end{array}$ \\
\hline$u_{t}$ & & & & $\begin{array}{c}-0.715 \\
(0.167) \\
{[0.0001]}\end{array}$ & \\
\hline$\pi_{t-4}^{e 1}$ & & $\begin{array}{c}-0.456 \\
(0.498) \\
{[0.3638]}\end{array}$ & & & \\
\hline$\pi_{t-1}^{e 1}$ & & & $\begin{array}{c}-0.386 \\
(0.447) \\
{[0.3913]}\end{array}$ & & \\
\hline $\mathrm{R}^{2}$ & 0.30 & 0.31 & 0.31 & 0.20 & 0.12 \\
\hline Adjusted $\mathrm{R}^{2}$ & 0.27 & 0.27 & 0.27 & 0.18 & 0.10 \\
\hline S.E. & 1.53 & 1.54 & 1.54 & 1.63 & 1.71 \\
\hline DW & 1.77 & 1.74 & 1.71 & 1.47 & 1.34 \\
\hline
\end{tabular}

Note: Ordinary least squares. The dependent variable is $\pi_{t}$, quarterly inflation at an annual rate in quarter $t$. $u_{t}$ denotes the unemployment rate in quarter $t$, and $\pi_{t-1}^{e 1}$ and $\pi_{t-4}^{e 1}$ denote expectations in quarter $t-1$ and $t$-4, respectively, of annual inflation 1 year ahead. Stand errors within parenthesis; pvalues within brackets.

Columns (2) and (3) show the result of including inflation expectations as explanatory variables. In column (2), I include 1-year-ahead inflation expectations lagged 4 quarters, as in a New Classical Phillips curve. This case may well be consistent with Swedish wage-setting, as discussed above, when nominal wages are set one year ahead. However, as discussed above, there is some evidence that wages are set conditional on inflation equaling the inflation target of 2 percent. The coefficient is not significantly different from zero, consistent with such wage-setting. An alternative interpretation is that inflation expectations vary too little to have any explanatory power in this regression. Column (3) shows the result of including 1-year-ahead inflation expectations lagged 1 quarter. This is in line with a New Keynesian Phillips curve. I use a 1-quarter lag of inflation expectations to avoid obvious simultaneity problems. A separate test with two-stages least squares of current inflation expectations as an explanatory variable is conducted among the robustness tests in section 5. A zero coefficient cannot be rejected.

Columns (4) and (5) show the restriction to either only current or only lagged unemployment in the Phillips curve. Clearly, the fit is worse, and serially uncorrelated error terms can be rejected. 


\subsection{The long-run Phillips curve}

The benchmark specification of the short-run Phillips curve is hence

$$
\pi_{t}=\gamma_{0}-\gamma_{1}\left(u_{t}-u_{t-1}\right)-\gamma u_{t-1}+\varepsilon_{t},
$$

with the change in unemployment and one lag of unemployment, but no lags of inflation, as explanatory variables.

Taking the unconditional mean of the short-run Phillips curve (7) and using $\pi=\mathrm{E}\left[\pi_{t}\right], u=\mathrm{E}\left[u_{t}\right]$, and $\mathrm{E}\left[\varepsilon_{t}\right]=0$ then results in the long-run Phillips curve

$$
\pi=\gamma_{0}-\gamma u
$$

where $\gamma$, the coefficient on lagged unemployment, is thus the slope of the long-run Phillips curve.

From the estimates in table 2, it follows that the slope of the long-run Phillips curve is about 0.8. With a standard error of 0.19 , it is fairly precisely estimated. The 95-percent confidence interval of the slope is the interval from 0.43 to 1.18 . If four lags of inflation are added to (7), a Wald test does not reject the hypothesis that the coefficients on the inflation lags are zero. ${ }^{17}$ Clearly, the hypothesis of a vertical Phillips curve, an infinite slope, can be rejected.

The rejection of a vertical Phillips curve is in contrast to the case in Rudebusch and Svensson (1999) where a Phillips curve for the U.S. economy is estimated for the sample 1961Q1-1996Q2. The hypothesis that the coefficients on lagged inflation sum to unity cannot be rejected. Instead, the estimation is done under the restriction that the coefficients sum to unity and thus the long-run Phillips curve is vertical.

Figure 6 shows the long-run Phillips curve (8) for the estimates in table 2 (black solid and dashed line) with a scatter plot with quarterly CPI inflation at an annual rate and unemployment for the sample 1997Q4-2011Q4 (circles with connecting lines). The long-run Phillips curve is solid for average inflation rates of less than 1 percentage point from 2 percent and dashed for average inflation rates further from 2 percent, in order to emphasize that it is derived under the assumption that average inflation expectations are equal to 2 percent. It may apply only if average inflation does not deviate too far from 2 percent. If average inflation were to deviate far from 2 percent, in line with the reasoning of ADP, a higher fraction of the private-sector would have rational expectations and the long-run Phillips curve might bend and become steeper. However, downward rigidity of nominal wages could for inflation rates close to zero counteract this.

\footnotetext{
${ }^{17}$ The p-value is about 0.37 .
} 
Figure 6. The long-run Phillips curve and scatter plot, 1997Q4-2011Q4

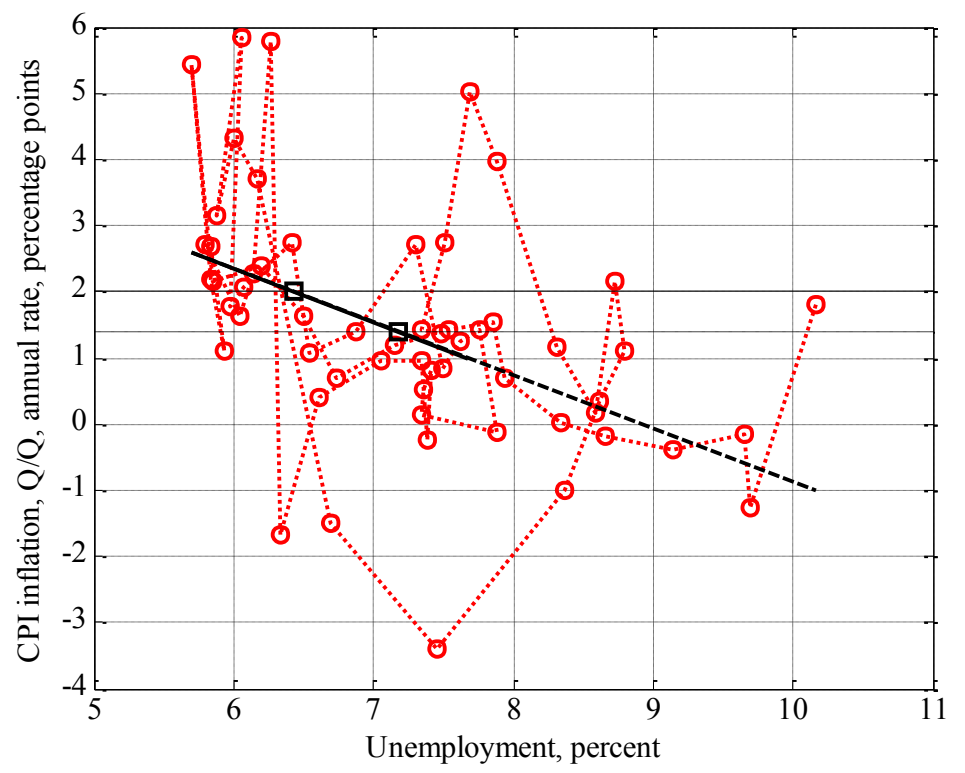

The slope of the long-run Phillips curve is sensitive to the starting date of the sample. Figure 7 shows the long-run Phillips curve and the scatter plot for the sample 1997Q1-2011Q4, that is, with an earlier sample start. The curve slope is less, 0.46 . We see in figure 7 that the observations in early 1997, to the right in the figure with high unemployment and inflation not too far from 2 percent, make a flatter long-run Phillips curve fit better.

Figure 7. The long-run Phillips curve and scatter plot, 1997Q1-2011Q4

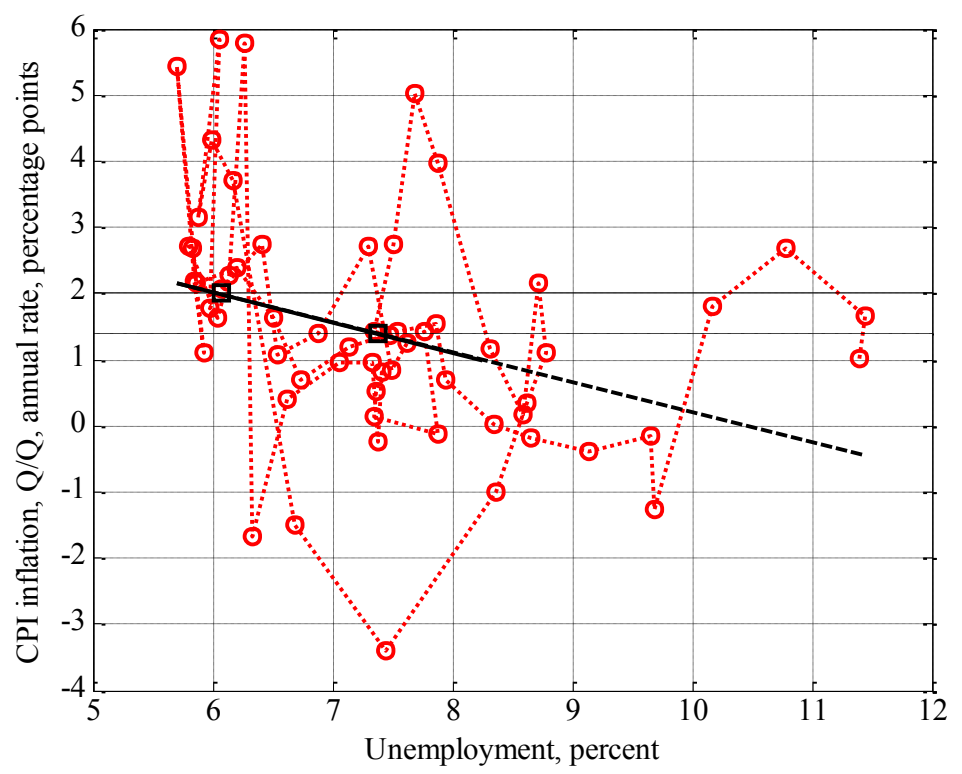

Figure 8 shows the slope of the long-run Phillips curve, the coefficient $\gamma$, as a function of the sample starting date, with all samples ending 2011Q4. The figure also shows 95-percent confidence intervals (plus/minus two standard errors of the estimate of the slope). The slope varies, from a minimum of 0.46 for the sample start 1997Q1 to a maximum of 0.88 for 1998Q1, and then falls to 0.7 for 1999Q2. The average over the sample starts 1997Q1-1999Q2 is 0.73. A low slope will result in a high unemployment cost of average inflation below the target, whereas a high slope will result in a low 
unemployment cost. The highest lower bound of the 95-percent confidence interval is 0.49 and occurs for the sample start 1998Q1. The lowest higher bound of the 95-percent confidence interval is 0.76 and occurs for 1997Q1. From this, a benchmark of 0.75, a relatively high slope of the long-run Phillips curve, close to the lowest higher bound of the 95-percent confidence interval, seems a rather conservative estimate that will not exaggerate the unemployment cost. It is somewhat lower than the slope of the long-run Phillips curve for the sample 1997Q4-2011Q4 reported in table 2 and figure 6.

As a benchmark 95-percent confidence interval around the benchmark slope of 0.75 , I will use \pm 0.35 , that is, the interval $[0.4,1.1]$. The benchmark slope is the average of the estimated slope for the sample starts 1997Q3 and 1997Q4 in figure 8, and the benchmark confidence interval is then the average of the estimated confidence intervals for these sample starts.

Figure 8. The slope of the long-run Phillips curve: Sample start 1997Q1-1999Q2

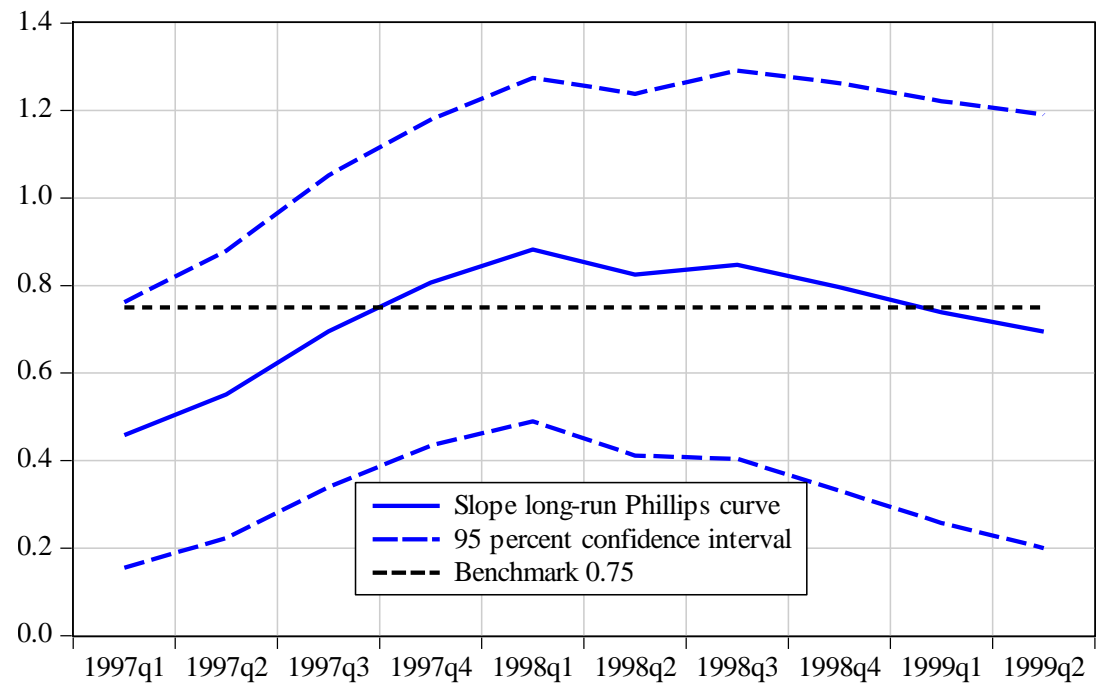

\section{The unemployment cost of average inflation below a credible target}

The benchmark slope of the long-run Phillips curve, 0.75 , implies that 1 percentage point lower average inflation is associated with $1 / 0.75=1.33$ percentage points higher average unemployment. This means that the benchmark 0.6 percentage points average inflation below target implies a benchmark of $0.6 / 0.75=0.8$ percentage points higher average unemployment. Using the estimate in table 2 and figure 6, for the sample 1997Q4-2011Q4, as an illustration, the rightmost black square on the long-run Phillips curve in figure 6 shows the average unemployment associated with average inflation 0.6 percentage points below target. It is 7.18 percent. The leftmost black square shows the average unemployment associated with average inflation on target. It is 6.44 percent. ${ }^{18}$ The horizontal distance between the squares shows the unemployment cost of average inflation having fallen short of the target by 0.6 percentage points. It is 0.74 , somewhat less than the benchmark 0.8 , since the slope of the long-run Phillips curve in figure 6 is 0.81 and somewhat steeper than the benchmark 0.75.

\footnotetext{
${ }^{18}$ Under the assumption of a constant natural rate $u^{*}$, from (8) and (5) and table 2 it follows that $u^{*}=\left(\gamma_{0}-2\right) / \gamma=$ $5.19 / 0.81=6.44$, so this number can be seen as an estimate of a constant natural rate during 1997Q1-2011Q4. (The long-run Phillips curve estimated for 1997Q4-2011Q4 is considered to apply also for the beginning of 1997, and average inflation over 1997Q1-2011Q4 is used.) However, in the last few years, substantial structural reforms, tax changes, and other factors, including demography and labor force composition, have probably reduced the natural rate substantially according to Forslund (2008), Ministry of Finance (2011), and National Institute of Economic Research (2011).
} 
Since the slope of the long-run Phillips curve is sensitive to the sample start, so is excess average unemployment. Figure 9 shows the excess average unemployment, calculated as 0.6 divided by the slope of the long-run Phillips curve, as a function of the sample start. The figure also shows 95-percent confidence intervals, calculated as 0.6 divided by the upper and lower bound of the confidence intervals for the slope of the long-run Phillips curve. The lowest lower bound for the 95-percent confidence interval for excess average unemployment is 0.46 percentage points and occurs for 1998Q3. An excess average unemployment of close to 0.5 percentage points for a period of about 15 years is still pretty high. The highest lower bound is 0.79 percentage points and occurs for 1997Q1. The lowest upper bound for excess average unemployment is 1.22 percentage points and occurs for 1998Q1. From this it follows that the benchmark 0.8 percentage points for excess average unemployment is a rather conservative benchmark and hardly an exaggeration of the unemployment cost of average inflation below the target.

Figure 9. Excess average unemployment, sample start 1997Q1-1999Q2

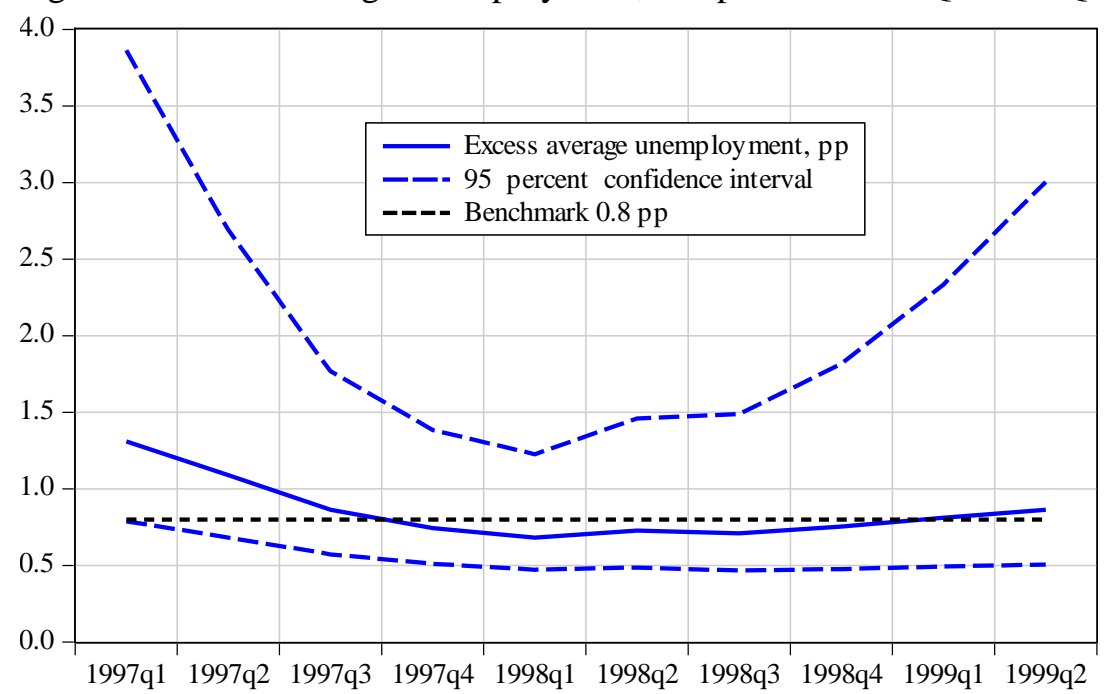

Thus, this analysis leads to a benchmark unemployment cost of about 0.8 percentage points excess unemployment on average during 1997-2011 due to average inflation having undershot the target by 0.6 percentage points during this period. This is a large unemployment cost of undershooting the inflation target.

I calculate the benchmark 95-percent confidence interval around the benchmark unemployment cost from the benchmark confidence interval of the slope $[0.4,1.1]$. This results in a benchmark confidence interval of $[0.6 / 1.1,0.6 / 0.4]=[0.55,1.5]$ percentage points for the unemployment cost. It is approximately equal to the average of the confidence intervals in figure 9 for the sample starts 1997Q3 and 1997Q4.

\subsection{Inflation and unemployment from 1976-2012}

Figure 10 shows a scatter plot with unemployment and annual CPI inflation from 1976Q1 through 2012Q4. We see that the observations during the 1970s and the 1980s with large fluctuations in inflation give the impression that the long-run Phillips curve was vertical at that point in time. The observations to the far right are from the big crisis in the early 1990s. The observations for the sample 1998Q1-2012Q4 are marked with solid connecting lines. ${ }^{19}$ The observations indicate a downwardsloping Phillips curve for that sample. The Riksbank’s inflation targeting and inflation expectations

\footnotetext{
${ }^{19}$ Since annual inflation from 1998Q1 and onwards is a moving average of the quarterly inflation of four quarters, it includes quarterly inflation from 1997Q1 and onwards.
} 
anchored to the target imply a regime shift. The figure also shows the benchmark long-run Phillips curve. The long-run Phillips curve goes through the point corresponding to average inflation equal to 1.4 percent and average unemployment equal to 7.2 percent, the average unemployment rate during the sample 1997Q4-2011Q1. ${ }^{20}$ This is the right black square on the long-run Phillips curve. The left black square marks the point on the long-run Phillips curve where average inflation equals 2 percent, the inflation target. The horizontal distance between the black squares is 0.8 percentage points, the excess average unemployment due to average inflation below the inflation target.

Figure 10. Unemployment and annual CPI inflation, 1976Q1-2012Q4, and the benchmark long-run Phillips curve, 1997-2011

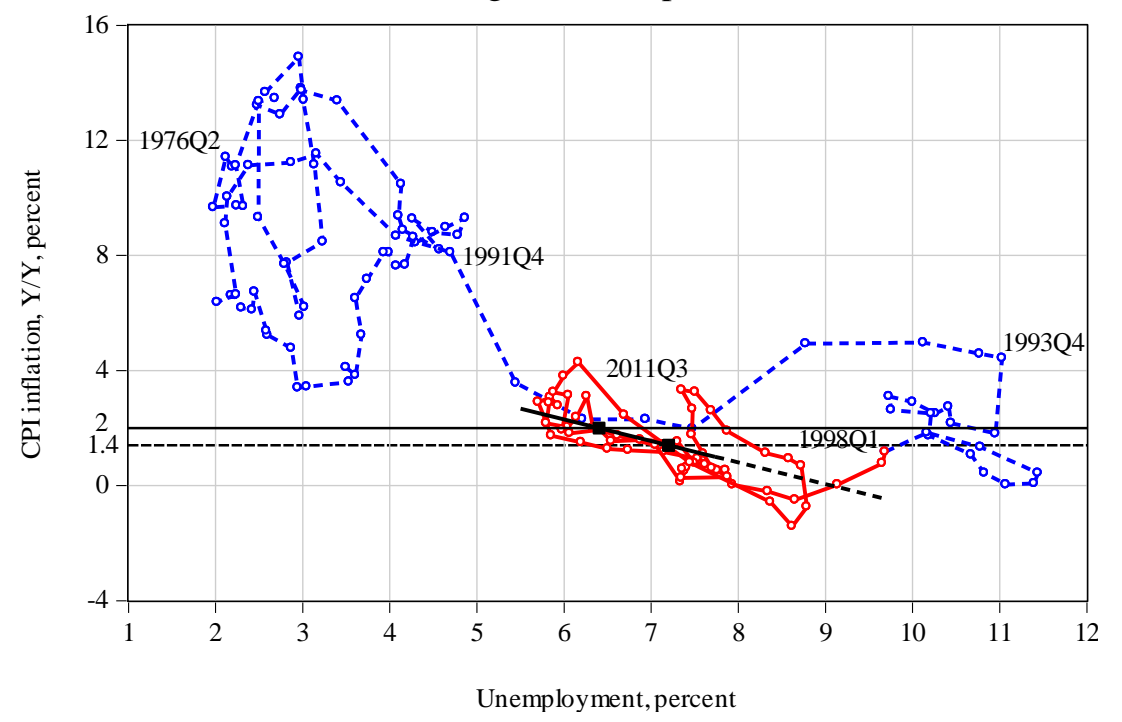

\section{Some robustness tests}

This section presents some robustness tests. One could argue that the crisis years 2008-2011 are special. If one limits the sample to 1997Q1-2007Q4, the average annual CPI inflation is 1.31, so the average inflation is about 0.7 percentage points below target. The estimated slope of a long-run Phillips curve for 1997Q4-2007Q4 is 0.83, so the average unemployment cost is about $0.7 / 0.83=0.85$ percentage points, somewhat higher than the $0.6 / 0.81=0.74$ percentage points average unemployment cost that follows from the estimate for 1997Q4-2011Q4 in table 2; see figure 11.

Through the Monetary Policy Update of April 2008, the Riksbank used CPIX inflation as an operational target rather than CPI inflation. From the Monetary Policy Report of July 2008, the Riksbank has emphasized CPIF inflation rather than CPIX inflation. The CPIF index was constructed in 2008 and did not exist before. As explained in Sveriges Riksbank (2008), the price index CPIX differs from the CPI in that the effects of changes in mortgage costs and the direct effects of changes in indirect taxes and subsidies are excluded. The price index CPIF differs from the CPI in that mortgage costs are calculated with a constant mortgage rate. Given this, one may want to consider the long-run Phillips curve with CPIX/CPIF inflation instead of CPI inflation, where CPIX/CPIF inflation refers to CPIX inflation through 2008Q1 and CPIF inflation from 2008Q2. ${ }^{21}$

\footnotetext{
20 The sample 1997Q4-2011Q4 excludes the three rightmost observations of high unemployment in figure 13.

21 Andersson, Palmqvist, and Österholm (2012) discuss the Riksbank target attainment for 1995-2011 in terms of CPIF inflation, and at the same time emphasize the relevance of using real-time data. Since the CPIF index did not exist before 2008 and the Riksbank used CPIX inflation before 2008 as an operational target, it is
} 
Figure 11. The long-run Phillips curve and scatter plot, 1997Q4-2007Q4

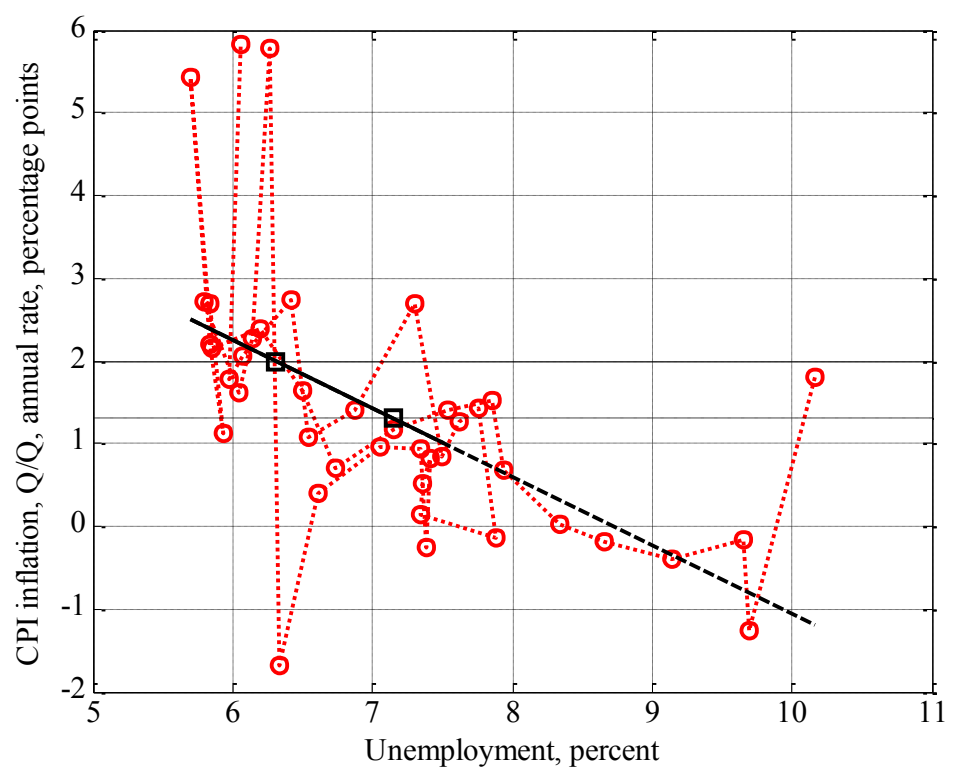

The Riksbank has also published an estimate of time-varying "long-term" unemployment. ${ }^{22}$ One may want to consider a long-run Phillips curve for an unemployment gap between unemployment and the Riksbank's long-term unemployment instead of just the unemployment rate. Figure 12 shows CPIX/CPIF inflation and the Riksbank's estimate of long-term unemployment together with CPI inflation and unemployment.

Figure 12. Annual CPI and CPIX/CPIF inflation, unemployment, and the Riksbank’s estimate of long-term unemployment

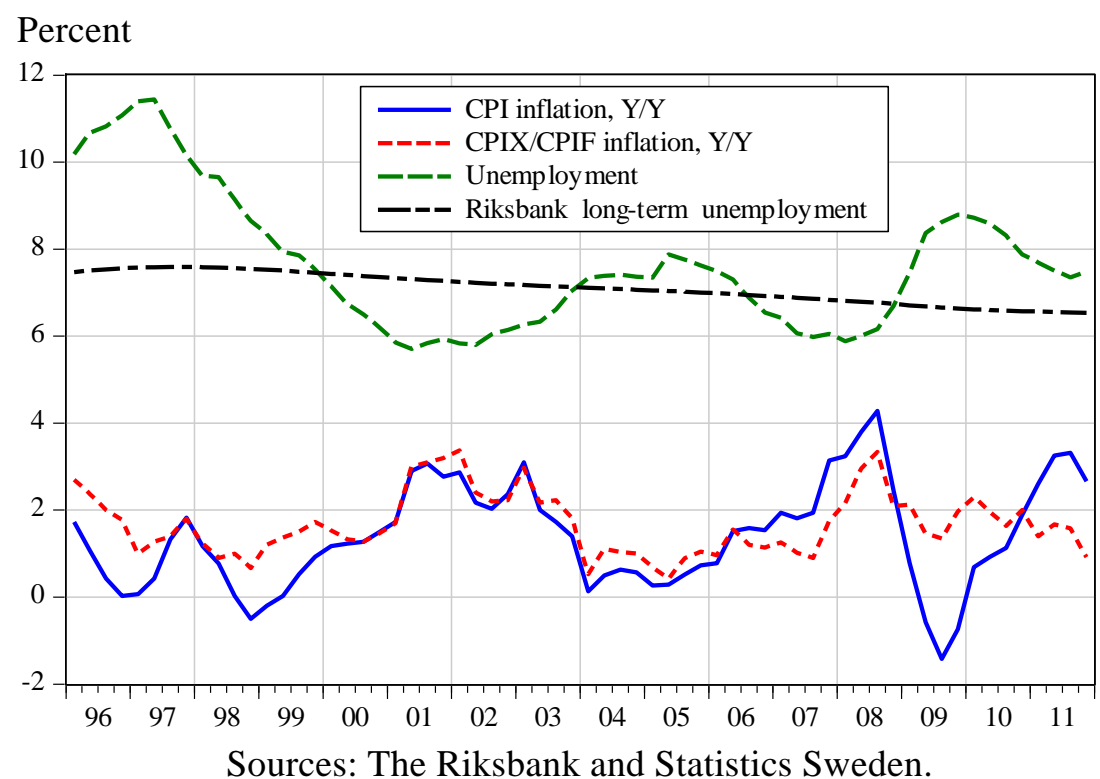

Average real-time CPIX/CPIF inflation was 1.64 percent during 1997-2011 and hence fell short of the target by about 0.4 percentage points. Estimating a long-run Phillips curve from the short-run Phillips curve (7) for unemployment with quarterly seasonally adjusted CPIX/CPIF inflation at an annual rate

arguably more relevant to discuss target attainment before 2008 in terms of CPIX inflation than in terms of CPIF inflation.

${ }^{22}$ The Riksbank’s estimate of long-term unemployment is shown in Sveriges Riksbank (2010, figure B23). 
instead of CPI inflation leads to a flatter long-run Phillips curve with a slope of 0.36 and a higher unemployment cost of $0.4 / 0.36=1.1$ percentage points. This is shown in figure 13. For CPIX/CPIF inflation, the fit is not as good as for CPI inflation. $R^{2}$ and adjusted $R^{2}$ are only 0.09 and 0.05 for CPIX/CPIF inflation compared with 0.30 and 0.27 for CPI inflation.

Figure 13. The long-run Phillips curve with CPIX/CPIF inflation and unemployment, 1997Q4-2011Q4

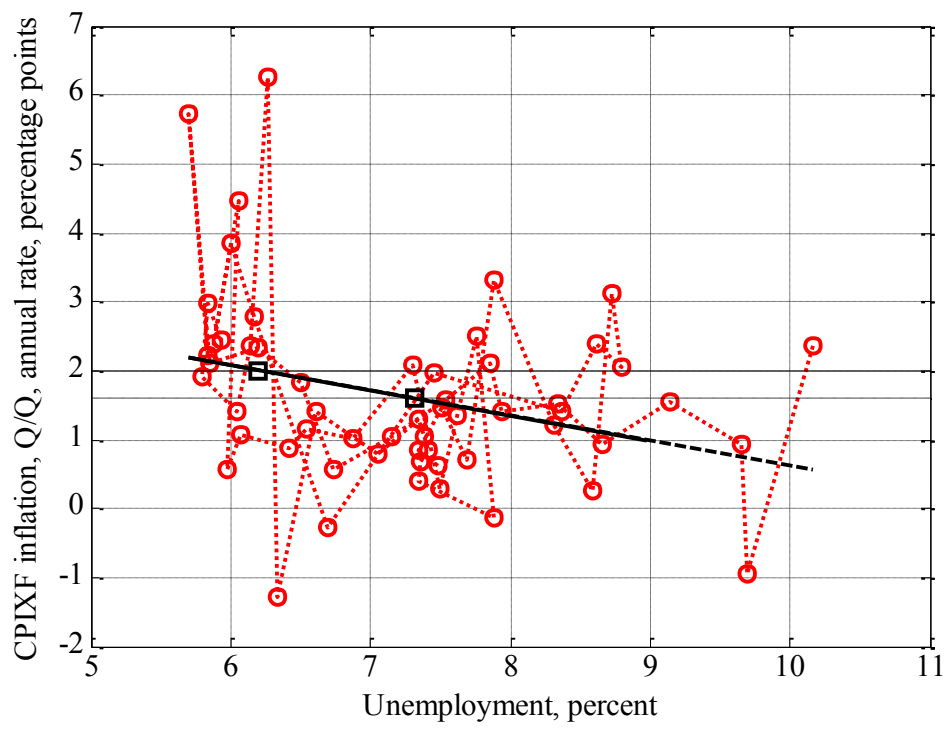

Using the benchmark specification (7) of the Phillips curve with CPI inflation, but with the gap between unemployment and the Riksbank's estimate of long-term unemployment instead of just unemployment, means estimating a short-run Phillips curve such as

$$
\pi_{t}=\gamma_{0}+\gamma_{1}\left[\left(u_{t}-u_{t}^{*}\right)-\left(u_{t-1}-u_{t-1}^{*}\right)\right]+\gamma\left(u_{t-1}-u_{t-1}^{*}\right)+\varepsilon_{t},
$$

where $u_{t}^{*}$ denotes a time-varying long-term unemployment rate rather than a constant natural rate.

Estimating this results in a flatter long-run Phillips curve with a slope of 0.65 and a larger unemployment (gap) cost, 0.93 percentage points, see figure 14. The fit is worse than with unemployment, with $\mathrm{R}^{2}$ and adjusted $\mathrm{R}^{2}$ equal to 0.22 and 0.19 , respectively.

Interestingly, the average unemployment gap associated with average inflation equal to the target is minus 0.75 , as shown by the leftmost black square in figure 14 . This indicates that the Riksbank's estimate is biased upwards. Naturally, estimates of any long-run unemployment rate from observed data from this sample period under the maintained assumption of rational expectations (or even just unbiased expectations) will be biased upwards, given that average inflation has systematically undershot average inflation expectations. Figure 15 shows a revised Riksbank estimate, constructed by just subtracting 0.75 from the Riksbank's estimate of the long-term unemployment rate. ${ }^{23}$

\footnotetext{
${ }^{23}$ Riksbank (2012) presents a new Riksbank estimate of the long-run sustainable rate of unemployment of 6.25 percent (the midpoint of an interval between 5 and 7.5 percent). In Svensson (2012), I argue that this estimate has an upward bias of 0.75 percentage points, and that a corrected Riksbank estimate should therefore be 5.5 percent.
} 
Figure 14. The long-run Phillips curve with CPI inflation and the Riksbank’s unemployment gap, 1997Q4-2011Q4

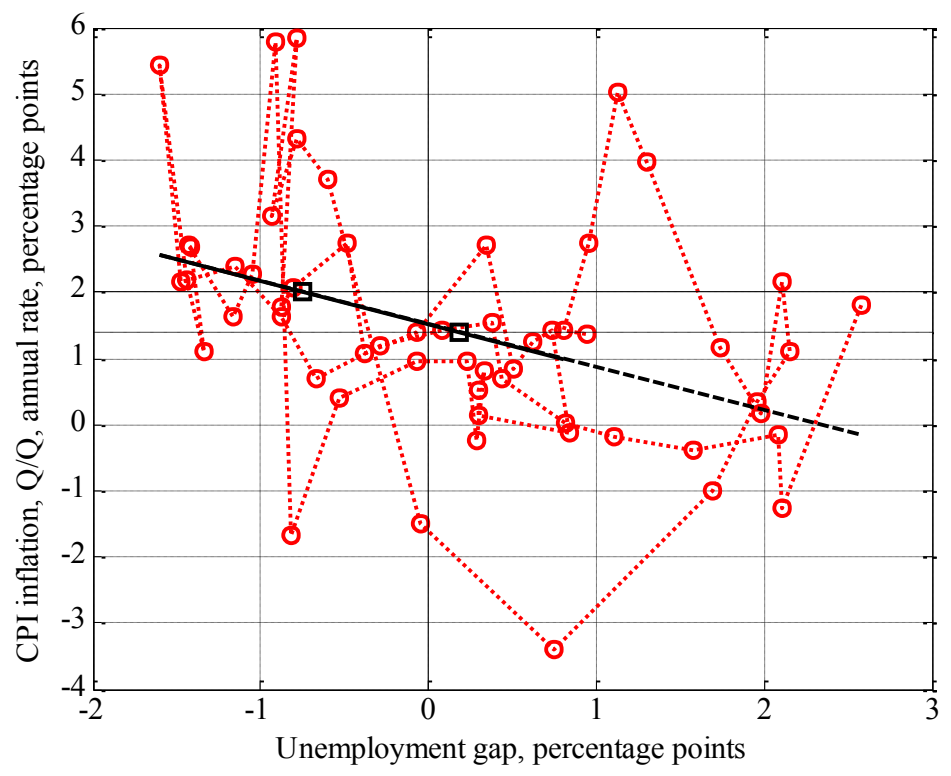

Figure 15. A revised Riksbank estimate of long-term unemployment, the Riksbank’s estimate of long-term unemployment, and annual CPI inflation

\section{Percent}

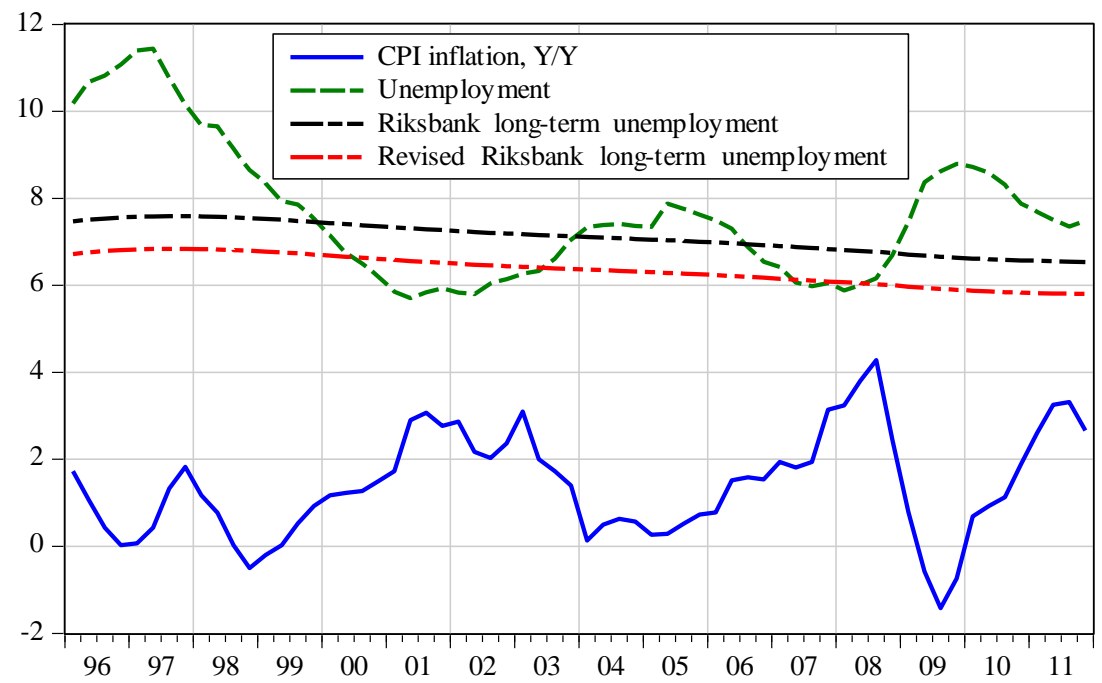

Sources: The Riksbank, Statistics Sweden, and own calculations.

In the estimated short-run Phillip curve (7), unemployment is considered to be predetermined and therefore uncorrelated with the error term. If we instead use the lagged change in the unemployment rate and a second lag of the unemployment rate as explanatory variables, that is, $u_{t-1}-u_{t-2}$ and $u_{t-2}$ on the right-hand side of (7), we get a flatter long-run Phillips curve with a slope of 0.64 and a higher unemployment cost of 0.93 percentage points; see figure 16 . The fit is worse with lagged unemployment than with current unemployment, with $\mathrm{R}^{2}$ and adjusted $\mathrm{R}^{2}$ equal to 0.23 and 0.20 , respectively. 
Figure 16. The long-run Phillips curve with CPI inflation and the lagged change in unemployment and a second lag of unemployment, 1997Q4-2011Q4

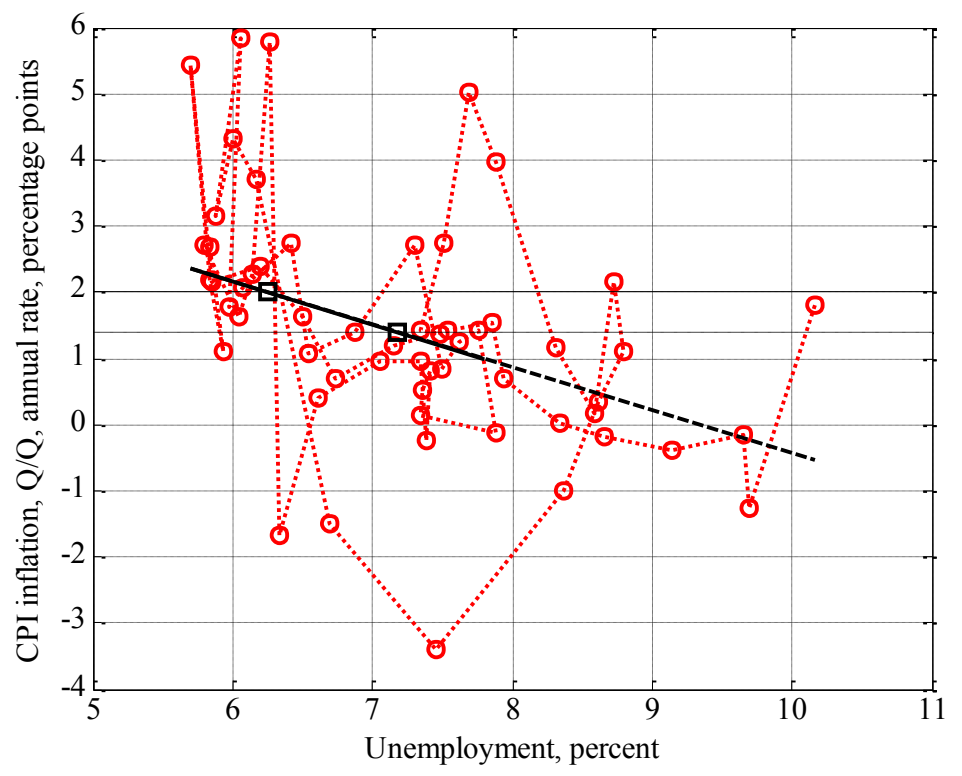

Another way of handling possible endogeneity and correlation between unemployment and the error term in (7) is to use instrumental variables. Column (1) in table 3 shows the results of a two-stage least squares estimation with three lags of unemployment as instruments. They are very similar to the OLS estimates in table 2.

Above, a specification with 1-year-ahead inflation expectations lagged 1 quarter was examined. If instead current inflation expectations are included, the dependence of inflation expectations on actual inflation creates a simultaneity problem. Column (2) shows the result of a two-stage least squares estimation, with three lags of unemployment, one lag of inflation expectations, and one lag of inflation as instruments. A zero coefficient on inflation expectations cannot be rejected.

The Phillips curve examined here is the one for CPI inflation, since the Riksbank's target and measures of inflation expectations refer to CPI inflation. The long-run Phillips curve estimated then represents the long-run tradeoff between the Riksbank's target variables, CPI inflation and unemployment. However, one could argue that, for an open economy such as Sweden, domestic inflation measured by the implicit GDP deflator might be more relevant for employment and unemployment, for instance, because the product wage might matter more for employment and unemployment than the CPI real wage. Column (3) in table 3 reports an estimate of the benchmark estimation but with inflation measured by the GDP deflator rather than the CPI. The fit is worse than for CPI inflation, the change in the unemployment is not significant, and there is serial correlation in the error term. Column (4) adds two lags (1 quarter and 3 quarters) of GDP-deflator inflation as explanatory variables (for lags 2 and 4 quarters, the estimated coefficient is close to zero). Then serially uncorrelated error terms cannot be rejected. The long-run slope is 0.66 (the coefficient of the lagged unemployment term divided by 1 minus the sum of the coefficients of the lagged inflation terms). The average inflation from 1997Q4-2011Q4 is about 1.5 percent, about 0.5 percentage points below the target. This means that the excess average unemployment is about 0.75 percentage points, similar to the benchmark estimate of 0.8 . The fit is not as good as for CPI inflation, and the precision of the estimate is less. 
Column (5) reports a regression with revised instead of real-time CPI inflation. We see that the slope of the long-run Phillips curve, coefficient of lagged unemployment, is not different from that in the benchmark specification, column (1) in table 2.

Table 3. Some robustness tests, 1997Q4-2011Q4

\begin{tabular}{|c|c|c|c|c|c|}
\hline & (1) & (2) & (3) & (4) & (5) \\
\hline $\begin{array}{l}\text { Dependent } \\
\text { variable }\end{array}$ & $\begin{array}{c}\text { CPI } \\
\text { Q/Q AR }\end{array}$ & $\begin{array}{c}\text { CPI } \\
\text { Q/Q AR }\end{array}$ & $\begin{array}{c}\text { GDP } \\
\text { deflator } \\
\text { Q/Q AR } \\
\end{array}$ & $\begin{array}{c}\text { GDP } \\
\text { deflator } \\
\text { Q/Q AR } \\
\end{array}$ & $\begin{array}{c}\text { CPI } \\
\text { Q/Q AR } \\
\text { Revised } \\
\end{array}$ \\
\hline Constant & $\begin{array}{c}7.344 \\
(1.462) \\
{[0.0000]}\end{array}$ & $\begin{array}{c}8.255 \\
(-3.070) \\
{[0.0096]}\end{array}$ & $\begin{array}{c}5.665 \\
(1.691) \\
0.0015\end{array}$ & $\begin{array}{c}6.812 \\
(1.732) \\
0.0002\end{array}$ & $\begin{array}{c}7.278 \\
(1.415) \\
{[0.0000]}\end{array}$ \\
\hline$u_{t}-u_{t-1}$ & $\begin{array}{c}-2.909 \\
(1.030) \\
{[0.0066]}\end{array}$ & $\begin{array}{c}-3.533 \\
(1.071) \\
{[0.0017]}\end{array}$ & $\begin{array}{c}-1.137 \\
(0.899) \\
{[0.2116]}\end{array}$ & $\begin{array}{c}-1.621 \\
(0.854) \\
{[0.0634]}\end{array}$ & $\begin{array}{c}-2.538 \\
(0.753) \\
{[0.0014]}\end{array}$ \\
\hline$u_{t-1}$ & $\begin{array}{c}-0.829 \\
(0.202) \\
{[0.0001]}\end{array}$ & $\begin{array}{c}-0.929 \\
(-0.296) \\
{[0.0028]}\end{array}$ & $\begin{array}{c}-0.579 \\
(0.232) \\
{[0.0155]}\end{array}$ & $\begin{array}{c}-0.722 \\
(0.225) \\
{[0.0023]}\end{array}$ & $\begin{array}{c}-0.830 \\
(0.194) \\
{[0.0001]}\end{array}$ \\
\hline$\pi_{t}^{e 1}$ & & $\begin{array}{c}-0.112 \\
0.583 \\
{[0.8483]}\end{array}$ & & & \\
\hline$\pi_{t-1}^{\mathrm{GDP}}$ & & & & $\begin{array}{l}-0.349 \\
(0.129) \\
{[0.009]}\end{array}$ & \\
\hline$\pi_{t-3}^{\mathrm{GDP}}$ & & & & $\begin{array}{c}0.259 \\
(0.125) \\
{[0.043]}\end{array}$ & \\
\hline $\mathrm{R}^{2}$ & 0.30 & 0.27 & 0.10 & 0.26 & 0.28 \\
\hline Adjusted $\mathrm{R}^{2}$ & 0.27 & 0.23 & 0.07 & 0.20 & 0.26 \\
\hline S.E. & 1.54 & 1.58 & 1.91 & 1.77 & 1.60 \\
\hline DW & 1.78 & 1.79 & 2.59 & 1.94 & 1.79 \\
\hline
\end{tabular}

Note: $u_{t}$ denotes the unemployment rate in quarter $t . \pi_{t}^{e 1}$ denotes expectations in quarter $t$ of annual inflation 1 year ahead, and $\pi_{t}^{\mathrm{GDP}}$ denotes quarterly GDP-deflator inflation at an annual rate. Column (1): 2SLS, instruments $u_{t-1}, u_{t-2}$, and $u_{t-3}$. Column (2): 2SLS, instruments $u_{t-1}, u_{t-2}, u_{t-3}, \pi_{t-1}^{e 1}$, and $\pi_{t-1}$ (quarterly CPI inflation at an annual rate). Column (3)-(5): OLS.

A possible source of correlation between unemployment and the error term might be inflation expectations depending on unemployment. In equation (1), if inflation expectations, $\boldsymbol{\pi}_{t}^{e}$, were to depend on unemployment, $u_{t}$, the error term, $\varepsilon_{t}$, in (7) would be correlated with $u_{t}$. However, a regression of inflation expectations on unemployment, lagged inflation, and lagged inflation expectations shows that inflation expectations do not depend on unemployment. The coefficient on employment is very small and not significant (see table A5.1 in appendix A5).

In summary, these robustness test indicate that the benchmark estimate of a slope of 0.75 of the longrun Phillips curve is robust to alternative assumptions and specifications. 


\section{A long-run Phillips curve for the U.S.}

The data indicate that stable inflation expectations around the inflation target in Sweden since 1997 have led to a non-vertical long-run Phillips curve for 1997-2011. Has the same happened in the U.S.?

As noted above, the United States did not have any explicit inflation target until the Federal Reserve announced a target of 2 percent for PCE inflation in January 2012. However, a widely held perception is that even prior to this, the Federal Reserve targeted a core inflation rate of about 2 percent. Over the period 2000-2011, average inflation for the core CPI index was 2.0 percent and for the core PCE deflator 1.9 percent. Figure 17 shows the U.S. unemployment rate, the CBO's estimate of February 2013 of the long- and short-run natural unemployment rate, the annual core-CPI inflation rate, and the quarterly core CPI inflation at an annual rate.

Figure 17. The U.S. unemployment rate, the CBO long- and short-run natural rates, annual core CPI inflation, and quarterly core CPI inflation at an annual rate, 1997-2012

Percent

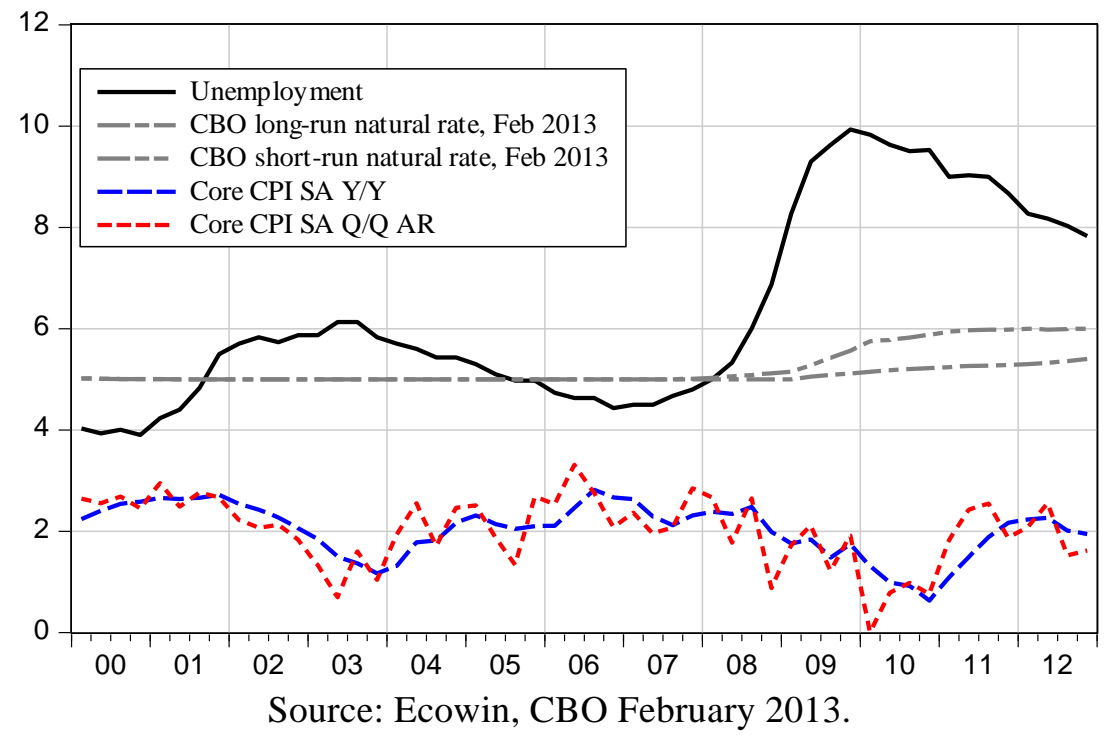

Fuhrer (2011) notes that various measures of inflation expectations have stabilized around 2 percent from 2000 onwards, and he notes that this implies that that there may be a non-vertical long-run Phillips curve in the U.S. Then, he estimates a long-run Phillips curve for quarterly core CPI inflation at an annual rate and an unemployment gap with a slope of 0.26 for the sample 2000Q1-2011Q2 (Fuhrer 2011, table 1).

A study of the same sample period as Fuhrer of the U.S. data with the same methods as those used above for Sweden leads to a Phillips curve of a somewhat different specification, namely with a 4quarter lag of inflation and a 1-quarter lag of unemployment but not the change in unemployment as explanatory variables,

$$
\pi_{t}=\gamma_{1}+\gamma_{2} \pi_{t-4}-\gamma_{3} u_{t-1}+\varepsilon_{t} \text {, }
$$

where $\pi_{t}$ denotes quarterly core CPI inflation at an annual rate in quarter $t$; $u_{t}$ denotes the unemployment rate; and $\varepsilon_{t}$ denotes a shock with an unconditional mean equal to zero. This specification fits the data well. Zero coefficients on other lags of inflation, zero coefficients on current and other lags of unemployment, and serially uncorrelated error terms cannot be rejected. Fuhrer uses 
an unemployment gap between the unemployment rate and the natural rate as the explanatory variable. The estimation results are not sensitive to whether the unemployment rate or an unemployment gap relative to the CBO's estimates of the natural rate is used, since the natural rate only varies at the end of the sample.

The result for the sample 2000Q1-2011Q2 is shown in table 4.

Table 4. A short-run Phillips curve for the U.S., 2000Q1-2011Q2

\begin{tabular}{cccc} 
Variable & Coefficient & Std. Error & Prob. \\
\hline Constant & 4.504 & 0.471 & 0.0000 \\
$\boldsymbol{\pi}_{t-4}$ & -0.332 & 0.129 & 0.0140 \\
$u_{t-1}$ & -0.304 & 0.047 & 0.0000 \\
\hline Note: OLS, $\mathrm{R}^{2}=0.50$, adjusted $\mathrm{R}^{2}=0.33$, S.E. $=0.52, \mathrm{DW}$ & $=1.56$.
\end{tabular}

The long-run Phillips curve is then given by (8), were $\gamma_{0}=4.504 / 1.332=3.381$ and $\gamma=0.304 / 1.332=0.228$. The slope is similar to the slope estimated by Fuhrer (2011). It is clear that the coefficient $\gamma_{2}$ is significantly different from unity, so the long-run Phillips curve is not vertical. This is in contrast to the Phillips curve estimated in Rudebusch and Svensson (1999) for the sample 1961Q11996Q2, for which the sum of the coefficients of four lags of inflation was not significantly different from unity.

Figure 18 shows U.S. unemployment and annual core CPI inflation during 1970-2012. The observations for the sample 2000Q1-2012Q4 are marked with solid connecting lines. We see that the data for 2000-2012 look different than the data for 1970-1999, consistent with inflation expectations having stabilized from 2000 onwards. The estimated long-run Phillips curve is shown as the black line. Figure 19 shows unemployment and quarterly core CPI inflation at an annual rate together with the long-run Phillips curve.

We realize from figure 19 that the slope of the Phillips curve is affected by the observations during the crisis period after 2008. Without these observations, the curve would be steeper. Thus, the U.S. longrun Phillips curve is less stable to variations in the sample end than the Swedish long-run Phillips curve.

Since average core CPI inflation is 2 percent and there is a widely held perception of an unofficial Federal Reserve inflation target of about 2 percent during the period, there is no unemployment cost of average inflation below the perceived target for the U.S. 
Figure 18. Unemployment and annual core CPI inflation in the U.S., 1970Q1-2012Q4, and a long-run Phillips curve, 2000Q1-2011Q2

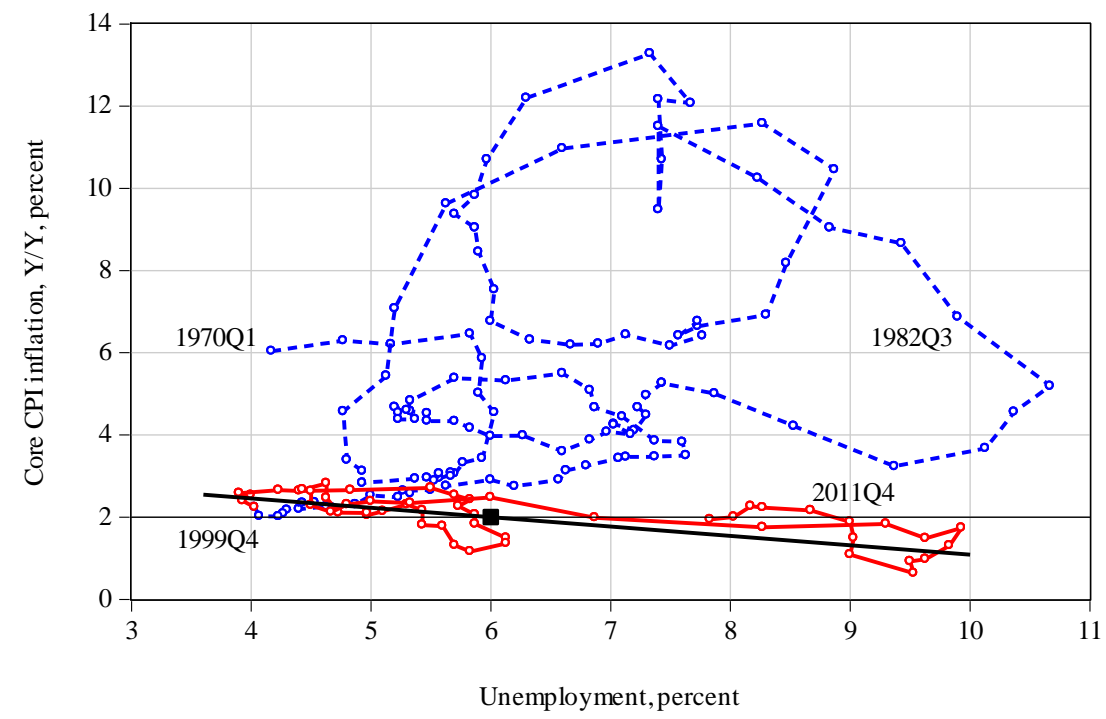

Figure 19. Unemployment and quarterly core CPI inflation at an annual rate in the U.S., 2000-2012, and a long-run Phillips curve, 2000Q1-2011Q2

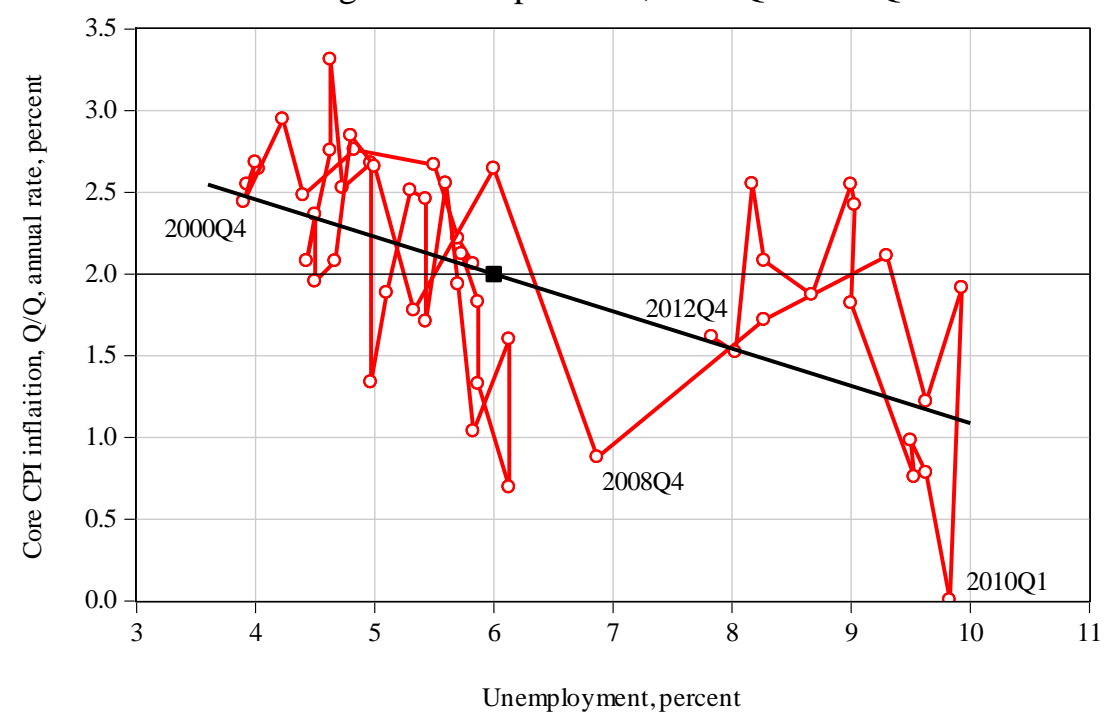

\section{A long-run Phillips curve for Canada}

As mentioned, Canada has had an inflation target since 1991, which from the end of 1995 is 2 percent for CPI inflation. Average CPI inflation over 1997-2011 is 2.0 percent. Does Canada have a nonvertical long-run Phillips curve during this period? Figure 20 shows the unemployment rate, annual CPI inflation, and quarterly CPI inflation at an annual rate during 1997-2012. 
Figure 20. Unemployment, annual CPI inflation, and quarterly CPI inflation at an annual rate in Canada, 1997-2012 Percent

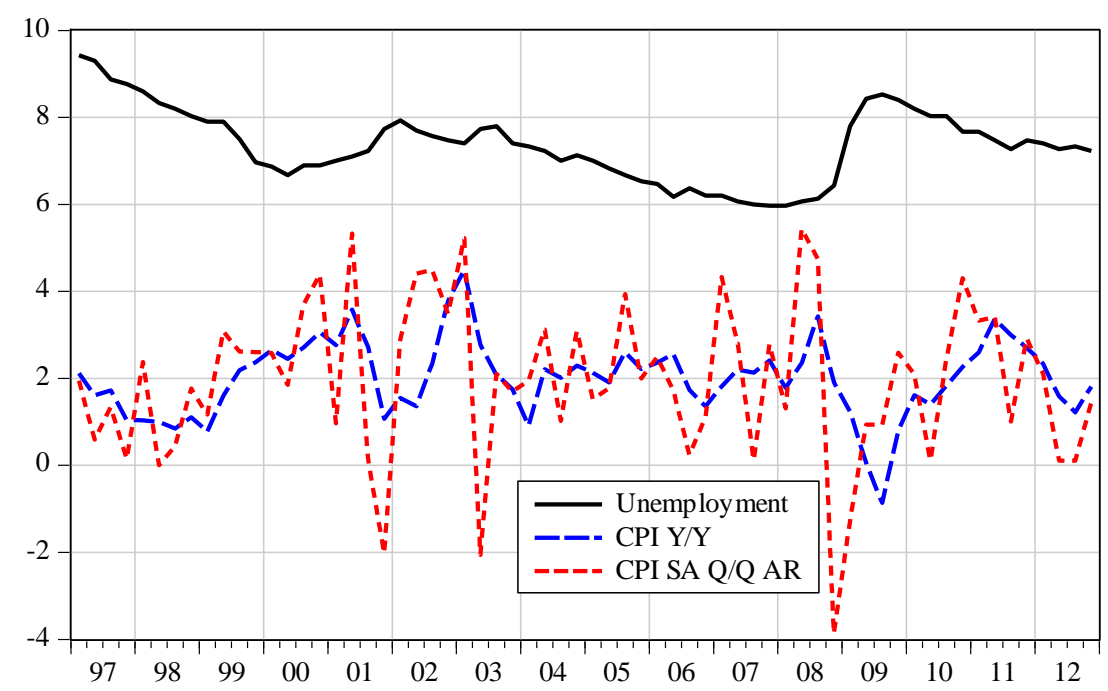

In figure 21 we see a scatter plot of unemployment and annual CPI inflation for the longer sample 1970Q1-2012Q4, with the observations from the sample 1997Q1-2012Q4 marked with solid connecting lines. We see that the data look different during the latter sample, consistent with stable inflation expectations and a non-vertical long-run Phillips curve.

Figure 21. Unemployment and annual CPI inflation in Canada, 1970-2012, and a long-run Phillips curve, 1997Q1-2012Q4

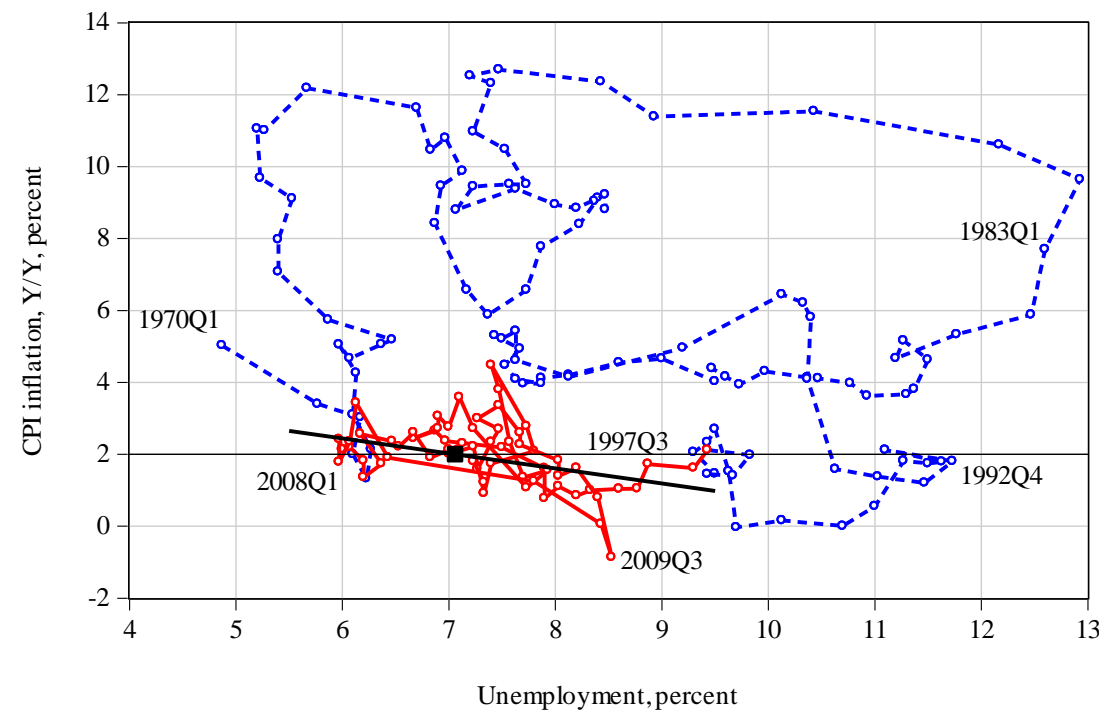

An estimation of the short-run Phillips curve (6) for Canada results, as in the Swedish case, in the specification (7) fitting the data well. The result is reported in table 5. Wald tests do not reject that the coefficients on lags of inflation or more lags unemployment are zero. Serially uncorrelated error terms cannot be rejected. The long-run Phillips curve has a slope of 0.42 .

Figure 22 shows the observations of unemployment and CPI inflation during 1997-2012 and the longrun Phillips curve. Since average inflation has been exactly on target in Canada, there is no unemployment cost of average inflation below target. 
Table 5. A short-run Phillips curve for Canada, 1997Q1-2012Q4

\begin{tabular}{cccc} 
Variable & Coefficient & Std. Error & Prob. \\
\hline Constant & 4.942 & 1.510 & 0.0018 \\
$u_{t}-u_{t-1}$ & -2.570 & 0.579 & 0.0000 \\
$u_{t-1}$ & -0.417 & 0.201 & 0.0426
\end{tabular}

Note: $\overline{\mathrm{OLS}, \mathrm{R}^{2}=0.14 \text {, adjusted } \mathrm{R}^{2}=0.11 \text {, S.E. }=1.72, \mathrm{DW}}=2.12$.

Figure 22. Unemployment and quarterly CPI inflation at an annual rate in Canada, 1997-2012, and a long-run Phillips curve, 1997Q1-2012Q4

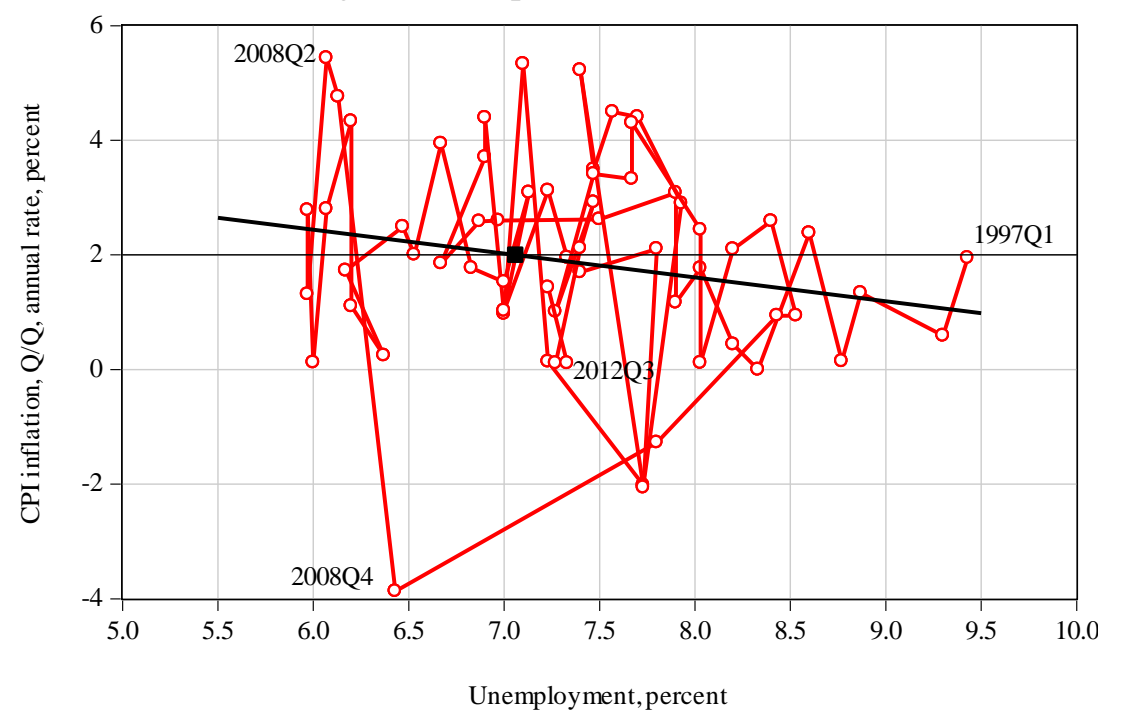

\section{Conclusions}

By 1997, the new inflation-targeting regime in Sweden had been established, in the sense that the inflation target was credible (inflation expectations were in line with the target), the repo rate (the Riksbank's policy rate) had been lowered to a normal level, and the Riksbank had had a few years to learn how to conduct inflation targeting. Over the next 15 years, 1997-2011, average CPI inflation has fallen short of the inflation target of 2 percent by 0.6 percentage points. But average inflation expectations according to the Prospera survey have been close to the target. Thus, average inflation expectations have been anchored to the target and the target has been credible. If average inflation expectations are anchored to the target when average inflation differs from the target, the long-run Phillips curve is not vertical. Then, lower average inflation means higher average unemployment. The data indicate that the slope of the long-run Phillips curve is about 0.75 . Then, average inflation below target has been associated with average unemployment being about 0.8 percentage points higher over the 15 years of 1997-2011 than what would have been the case if average inflation had been equal to the target. This is a large unemployment cost of average inflation below a credible target. Some simple robustness tests indicate that the estimate of the unemployment cost is rather robust.

A recent commentary by Söderström and Vredin (2013) argues that my estimate of the unemployment cost is too large. They use the Riksbank's DSGE model Ramses to conduct an experiment where unanticipated shocks to the Riksbank's policy rule reduce average CPIF inflation by 0.2 percentage points during 15 years, the length of the period 1997-2011. They find that average unemployment increases by about 0.25 percentage points, about a third of my estimate of 0.8 percentage points. 
However, unanticipated shocks to the monetary-policy rule that reduce average CPIF-inflation over 15 years also reduce CPI inflation by the same amount, in this case 0.2 percentage points. Hence, their experiment closes only a third of the gap between actual average CPI inflation and the inflation target. If they were to use their method to close the full gap between average CPI inflation and inflation, average unemployment would increase three times as much, that is, by about 0.75 percentage points. This is obviously very similar to my estimate, about 0.8 percentage points. Thus, Söderström and Vredin actually confirm rather than disprove my result. ${ }^{24}$

For the U.S., as noted by Fuhrer (2011) and confirmed here, there seems to be a non-vertical long-run Phillips curve from 2000 onwards. Since average core inflation has been equal or close to what is widely perceived as an unofficial Federal Reserve inflation target of about 2 percent from 2000 until the announcement of an official target in January 2012, there is no unemployment cost of average inflation below the perceived target for the U.S. For Canada, there seems to be a non-vertical long-run Phillips curve from 1997 onwards. Since average inflation has been equal to the target, there is no unemployment cost of average inflation below the target for Canada. Average inflation significantly below the target and a substantial average unemployment cost of this seems to be a Swedish phenomenon.

The difference between average inflation and average inflation expectations in Sweden and the evidence of the existence of a downward-sloping long-run Phillips curve raises several questions. Why has average inflation fallen short of the target for 15 years? Certainly, the experience of Australia, Canada, and the U.K. shows that it is possible to instead keep average inflation quite close to the target during such a long period. What are possible policy implications for the future? Do these findings make price-level targeting or the targeting of average inflation over a longer period relatively more attractive, since they would better ensure that average inflation over longer periods equals the target?

In a background study of the 2012 IMF Article-IV report on Sweden, Batini and Ishi (2012) note four possible reasons why the Riksbank has undershot the inflation target during the 1997-2011 period:

One possibility is that (1) the Riksbank may have conducted monetary policy in an asymmetric manner, de facto favoring lower inflation outcomes to higher ones. Alternatively, despite symmetric stabilization preferences, (2) the Bank may have systematically overestimated potential unemployment. (This is reminiscent of the argument of Orphanides that the Fed caused too high inflation in the 1970s by underestimating potential unemployment). Or more generally, the Riksbank may have systematically overestimated inflationary pressures, one story being that (3) imported inflation systematically came in below expectations and (4) growth in productivity higher than expected. Last but not least, (5) (at least since the Great Recession) the pass-through from the repo rate to other rates, notably the mortgage rate, may have weakened, meaning that easy monetary conditions were not reflected de facto in an easier monetary stance, and implying a stronger disinflationary effect of policy than desired. (Batini and Ishi 2012, p. 39-40, numbering added)

\footnotetext{
${ }^{24}$ During 1997-2011, when average real time CPI inflation was about 1.4 percent, average CPIF inflation would have been about 1.8 percent, 0.4 percentage points higher ("would have been" is appropriate, since the CPIF index was constructed in 2008 and did not exist in real time before then). The reason for the difference is the downward trend in mortgage rates during the period, which is a reflection of the global downward trend of real interest rates and could not have been prevented by Swedish monetary policy. Changes in housing costs due to mortgage-rate changes are included in the index CPI but excluded from the CPIF. For average CPI inflation to equal 2 percent during 1997-2011, average CPIF inflation would have had to be 2.4 percent, 0.6 pp higher than 1.8 percent.
} 
To this one could add that (6) the Riksbank has missed or neglected a downward trend in mortgage rates, which has contributed to average CPI inflation being lower than average CPIX and CPIF inflation (this is a possible reason emphasized in Andersson, Palmqvist, and Österholm 2012) . Reasons (2)-(4) and (6) involve systematic mistakes or neglects during the 15-year period, mistakes or neglects without which average inflation might have been on target and unemployment about 0.8 percentage points higher. Reason (5), if only applying since the Great Recession, can account only for the last third of the 15-year period. However, if there is a suspicion that monetary policy is too tight because it is less effective, the appropriate policy response is an easier policy than otherwise warranted. (This is an argument that I put forward several times at the policy meetings while I was at the Riksbank as a Deputy Governor and Executive Board member May 2007-May 2013.) Thus, these reasons hardly provide an excuse for undershooting the target and achieving higher average unemployment than necessary.

More generally, regardless of the reasons for the systematic undershooting of the inflation target, a more expansionary policy during 1997-2011 could both have brought average inflation in line with the target and created lower average unemployment. Given this, the unemployment loss during the 15year period was unnecessary. ${ }^{25}$

Since the first version of this paper was written, it has become increasingly clear that the main reason for low inflation in the last few years is that the majority of the Executive Board has pursued a tighter policy, resulting in lower inflation and higher unemployment, because of concerns about household debt. This is further discussed in Svensson (2013), including the possibility that such a policy is counterproductive as a way to reduce household debt, in that it actually increases rather than reduces real debt and the debt-to-GDP ratio, since tighter policy is likely to have a slower impact on nominal debt than on the price level and nominal GDP.

What are the policy implications for the future? I believe the main policy conclusion to be that if one wants to avoid the average unemployment cost, it is important to keep average inflation over a longer period in line with the target, a kind of average inflation targeting (Nessén and Vestin 2005). This could also be seen as an additional argument in favor of price-level targeting, with a price-level target rising at the rate of the inflation target. On the other hand, in Australia, Canada, and the U.K., and more recently in the euro area and the U.S., the central banks have managed to keep average inflation on or close to the target (the implicit target when it is not explicit) without an explicit price-level targeting framework.

Should the central bank try to exploit the downward-sloping long-run Phillips curve and secretly, by being more expansionary, try to keep average inflation somewhat above the target, so as to induce lower average unemployment than for average inflation on target? Such a policy would involve the central bank saying one thing (the target is 2 percent) and deliberately doing another (keeping average inflation above 2 percent). This would be inconsistent with an open and transparent monetary policy. Regardless of the moral quality of the policy, the truth might eventually be leaked or discovered, in which case the inflation target would lose credibility and inflation expectations would rise above the target, in which case the possible benefit of inflation above target would vanish.

\footnotetext{
${ }^{25}$ See appendix A2 for details.
} 


\section{References}

Akerlof, George A., William T. Dickens, and George L. Perry (2000), "Near-Rational Wage and Price Setting and the Long-Run Phillips Curve,” Brookings Papers on Economic Activity 1:2000, 1-44.

Andersson, Björn, Stefan Palmqvist, and Pär Österholm (2012), “The Riksbank’s Attainment of its Inflation Target over a Longer Period of Time,” Economic Commentary No. 4, 2012, Sveriges Riksbank, www.riksbank.se.

Batini, Nicoletta, and Kotaro Ishi (2012), “Sweden: Selected Issues,” IMF Country Report No. 12/155, www.imf.org.

Bergström, Villy, and Robert Boije (2005), "Monetary Policy and Unemployment,” Sveriges Riksbank Economic Review 4/2005, 15-49.

Bryan, Michael F., and Stefan Palmqvist (2010), “Testing Near-Rationality Using Survey Data,” in Sinclair, Peter (ed.), Inflation Expectations, ch. 10.

Facken inom industrin (2011), “Avtalspolitisk plattform” (Industrial Trade Unions, "Wage Negotiation Platform,” in Swedish), September 15, 2011, www.fackeninomindustrin.se.

Facken inom industrin (2012), “Avtalspolitisk platform - förslag” (Industrial Trade Unions, "Wage Negotiation Platform - Proposal,” in Swedish), November 12, 2012, www.fackeninomindustrin.se.

Flodén, Martin (2012), “A Note on Swedish Inflation and Expectations,” working paper, http://people.su.se/ mflod.

Forslund, Anders (2008), “Den svenska jämviktsarbetslösheten: en översikt,” (“The Swedish Equilibrium Unemployment Rate: A Survey,” in Swedish) Report to the Fiscal Policy Council, 2008/4, www.finanspolitiskaradet.se.

Fuhrer, Jeffrey C. (2011), "Inflation Expectations and the Evolution of U.S. Inflation,” Public Policy Brief No. 11-4, Federal Reserve Bank of Boston, www.bostonfed.org.

Gottfries, Nils (2012), Swedish Wage Formation - Does It Work? (in Swedish with English Summary), Report to the Swedish Long-term Commission of Inquiry.

Harri, Ardian, and B. Wade Brorsen (2009), “The Overlapping Data Problem,” Quantitative and Qualitative Analysis in Social Sciences 3, 78-115, www.qass.org.uk.

IMF (2013), “The Dog That Didn’t Bark: Has Inflation Been Muzzled or Was It Just Sleeping?” World Economic Outlook, April 2013, chapt. 3, www.imf.org.

Jonsson, Thomas, and Pär Österholm (2012), "The Properties of Survey-Based Inflation Expectations in Sweden,” Empirical Economics 42, 79-94.

Lindbeck, Assar, and Dennis Snower (2001), “Insiders versus Outsiders,” Journal of Economic Perspectives 15(1), 165-188.

Lundborg, Per, and Hans Sacklén (2006), "Low-inflation Targeting and Long-run Unemployment," Scandinavian Journal of Economics 108, 397-418. 
Ministry of Finance (2011), “Hur ska utvecklingen av arbetsmarknadens funktionssätt bedömas?” ("How to assess the development of the labor market's way of functioning?" in Swedish), Report from the Economics Department, Ministry of Finance, www.sweden.gov.se/sb/d/2062.

Morin, Mats (2009), “Löneutrymmet i en djup lågkonjunktur” (“The Scope for Wage Increases in a Deep Recession,” in Swedish), LO (The Swedish Trade Union Confederation), www.lo.se.

National Institute of Economic Research (2011). The Swedish Economy December 2011, www.konj.se.

National Institute of Economic Research (2012), Wage Formation in Sweden: Summary 2012, www.konj.se.

Nessén, Marianne, and David Vestin (2005), “Average Inflation Targeting,” Journal of Money, Credit and Banking 37, 837-864.

Rogerson, Richard (1997), “Theory Ahead of Language in the Economics of Unemployment,” Journal of Economic Perspectives 11, 73-92.

Rudebusch, Glenn, and Lars E.O. Svensson (1999), “Policy Rules for Inflation Targeting,” in Taylor, John B. (ed.), Monetary Policy Rules, University of Chicago Press.

Söderström, Ulf, and Anders Vredin (2013), “Inflation, Unemployment and Monetary Policy,” Economic Commenary No. 1, 2013, www.riksbank.se.

Stock, James H., and Mark W. Watson (2010), "Modeling Inflation after the Crisis,” in Macroeconomic Challenges: The Decade Ahead. Proceedings of the Federal Reserve Bank of Kansas City 2010 Jackson Hole Symposium, www.kc.frb.org.

Svensson, Lars E.O. (1997), "Inflation Forecast Targeting: Implementing and Monitoring Inflation Targets,” European Economic Review 41, 1111-1146.

Svensson, Lars E.O. (2012), “Correcting the Riksbank's Estimate of the Long-Run Sustainable Rate of Unemployment,” Appendix 2 of Riksbank July 2012 Minutes, larseosvensson.se.

Svensson, Lars E.O. (2013), “Some Lessons from Six Years of Practical Inflation Targeting,” Sveriges Riksbank Economic Review 2013:3, 29-80.

Sveriges Riksbank (2004), “Changes in Calculation Methods for the Inflation Rate,” Inflation Report 2004/2, 45-48, www.riksbank.se.

Sveriges Riksbank (2008), “The Rate of Increase in the CPIX Will Be below the CPI for a Long Time,” Monetary Policy Report 2008/2, 49-51, www.riksbank.se.

Sveriges Riksbank (2010), “The Driving Forces behind Trends in the Economy Can Be Analysed Using a Production Function,” Monetary Policy Report 2010/3, 56-61, www.riksbank.se.

Sveriges Riksbank (2011), “New Round of Collective Bargaining in an Uncertain Economic Climate,” Monetary Policy Report 2011/3, 53-59, www.riksbank.se.

Sveriges Riksbank (2012), “The Long-Term Development on the Swedish Labour Market”, Monetary Policy Report 2012/2, 45-51, www.riksbank.se. 
Williams, John C. (2006), "Inflation Persistence in an Era of Well-Anchored Inflation Expectations," FRBSF Economic Letter 2006-27, www.frbsf.org.

\section{Appendix}

\section{A1. Wage-setting with inflation expectations equal to the inflation target}

Consider a situation with centralized wage-setting, where nominal wages are set a period in advance (for instance a year) in negotiations between a trade union and an employers' association. Assume that the negotiations result in a target $(\log )$ real wage for period $t$, denoted $W_{t}^{*}$, that results in a desired rate of employment (and an acceptable rate of unemployment). Assume that it varies with with (log) productivity in period $t$, denoted $a_{t}$, according to

$$
W_{t}^{*}=W^{*}+a_{t},
$$

where $w^{0}$ is a constant. The nominal $(\log )$ wage, $w_{t}$, is then set in period $t-1$ according to

$$
w_{t}=w_{t} 0+p_{t}^{e},
$$

where $p_{t}^{e}$ denotes expectations in period $t-1$ of the (log) price level in period $t$. Furthermore,

$$
p_{t}^{e}=p_{t-1}+\pi_{t}^{e},
$$

where $p_{t-1}$ denotes the (log) price level in period $t-1$ and $\pi_{t}^{e}$ denotes expectations in period $t-1$ of inflation in period $t$.

It follows that the nominal wage can be written

$$
w_{t}=a_{t}+p_{t-1}+\pi_{t}^{e}+w^{*},
$$

and that the change in the nominal wage is given by

$$
\Delta w_{t}=\Delta a_{t}+\pi_{t-1}+\Delta \pi_{t}^{e},
$$

where I have used that actual inflation, $\pi_{t}$, satisfies

$$
\pi_{t} \equiv p_{t}-p_{t-1}
$$

Under the assumption that inflation expectations equal the inflation target, $\pi^{*}$, we then have

$$
\Delta w_{t}=\Delta a_{t}+\pi_{t-1} \text {. }
$$

The actual $(\log )$ real wage in period $t$, denoted $\mathscr{W}$, satisfies

$$
W_{t} \equiv w_{t}-p_{t}=\left(W_{t}^{*}+p_{t-1}+\pi_{t}^{e}\right)-\left(p_{t-1}+\pi_{t}\right)=W_{t}^{*}+\pi_{t}^{e}-\pi_{t},
$$

where I have used (A1.2), (A1.3), and (A1.6).

It follows that

$$
W_{t}-W_{t}^{*}=\pi_{t}^{e}-\pi_{t}
$$

If I assume that inflation expectations, $\boldsymbol{\pi}_{t}^{e}$, equal the inflation target, $\boldsymbol{\pi}^{*}$, we have

$$
W_{t}-W_{t}^{*}=\pi^{*}-\pi_{t} \text {. }
$$


That is, average inflation below the inflation target will imply that the average real wage will exceed the target real wage, implying lower employment and higher unemployment than what is consistent with the target.

\section{A2. The average unemployment cost of average inflation below the target is independent of the reasons for missing the target}

Consider a stylized model, where the structural relation between inflation and unemployment is given by the short-run Phillips curve (7), reproduced here,

$$
\pi_{t}=\gamma_{0}-\gamma_{1}\left(u_{t}-u_{t-1}\right)-\gamma u_{t-1}+\varepsilon_{t},
$$

where $\pi_{t}$ and $u_{t}$ denote inflation and unemployment rates in period $t$ and $\varepsilon_{t}$ is an exogenous shock. Alternatively, interpret (A2.1) as the reduced-form relation between inflation and unemployment within the monetary-policy regime considered, where the regime in particular is characterized by inflation expectations anchored at a fixed inflation target. Assume that the unemployment rate in period $t$ can be affected by a stylized policy instrument in period $t-1, i_{t-1}$, according to

$$
u_{t}=\alpha i_{t-1}+\eta_{t}
$$

where $\eta_{t}$ is an exogenous shock. The unanticipated shocks in (A2.1) and (A2.2) may contribute to inflation deviating from the target.

Consider sample averages over a given sample (for instance, 1997-2011),

$$
\begin{gathered}
\bar{\pi}=\gamma_{0}-\gamma \bar{u}+\bar{\varepsilon}, \\
\bar{u}=\alpha \bar{i}+\bar{\eta},
\end{gathered}
$$

where a bar over a variable denotes its sample average ( $\bar{i}$ denotes the sample average of $i_{t-1}$ ) and the sample average of $u_{t}-u_{t-1}$ is assumed to be zero. Let $\bar{u}^{0}$ denote the hypothetical sample average unemployment rate that is consistent with a sample average inflation rate equal to the inflation target, $\pi^{*}$. It satisfies the identity

$$
\pi^{*} \equiv \gamma_{0}-\gamma \bar{u}^{0}+\bar{\varepsilon}
$$

Define the excess average unemployment rate as $\bar{u}-\bar{u}^{0}$. It follows from (A2.3) and (A2.5) that the excess average unemployment rate is given by

$$
\bar{u}-\bar{u}^{0}=\left(\pi^{*}-\bar{\pi}\right) / \gamma .
$$

Thus, the excess average unemployment rate is independent of the sample averages of the exogenous shocks, $\bar{\varepsilon}$ and $\bar{\eta}$. The sample averages of the shocks may be part or all of the reason why average inflation has deviated from the target. The excess average unemployment rate is the average unemployment cost of average inflation below the target that is being estimated in this paper. Thus, it is independent of unanticipated shocks that may explain why average inflation has deviated from the target.

Note that $\bar{u}^{0}$ is a sample average and not necessarily the (long-run) natural rate, the sustainable rate of unemployment, denoted $u^{*}$. The latter might in this stylized model be defined as the sample average consistent with average inflation equal to $\pi^{*}$ and the sample average of $\varepsilon_{t}$ equal to zero. Then, the natural rate satisfies the identity 


$$
\pi^{*} \equiv \gamma_{0}-\gamma u^{*}
$$

The excess of $\bar{u}^{0}$ over the natural rate is given by

$$
\bar{u}^{0}-u^{*}=\left(\pi^{*}-\bar{\pi}\right) / \gamma+\bar{\varepsilon} / \gamma
$$

and depends on the sample average $\bar{\varepsilon}$ of the shock in the Phillips curve (A2.1).

\section{A3. Steady-state equilibria with unemployment different from the natural rate}

In order to understand what steady-state equilibria are possible, start from the Phillips curve (1), which may represent a New Keynesian Phillips curve or a New Classical Phillips curve, depending on whether the inflation expectations are current expectations of future inflation or previous expectations of current inflation. Consider the unconditional mean, resulting in the long-run Phillips curve (2), reproduced here:

$$
\pi-\pi^{e}=-\gamma\left(u-u^{*}\right)
$$

Consider now two alternative aggregate demand relations. First, consider a somewhat ad hoc aggregate-demand relation,

$$
u_{t}-u^{*}=\sigma\left(r_{t}-r_{t}^{*}\right)
$$

where $r_{t}$ denotes a real policy rate that the central bank can control, $r_{t} *$ is an exogenous stochastic neutral real interest rate, and $\sigma$ is a positive constant. Taking the unconditional mean, we have

$$
u-u^{*}=\sigma\left(r-r^{*}\right)
$$

Second, consider a New Keynesian aggregate-demand relation in the form of an Euler condition for the unemployment gap,

$$
u_{t}-u^{*}=\mathrm{E}_{t}\left(u_{t+1}-u^{*}\right)+\sigma\left(r_{t}-r_{t}^{*}\right),
$$

where $\mathrm{E}_{t}\left(u_{t+1}-u^{*}\right)$ denotes current expectations of the future unemployment gap. This can be derived from the standard Euler condition for the output gap, under the assumption that the output gap is proportional to the unemployment gap with the opposite sign. Taking the unconditional mean, we have

$$
r=r^{*} \text {. }
$$

Assume that in both cases, the central bank follows a policy rule of the form

$$
r_{t}-r^{*}=\alpha\left(\pi_{t}-\pi^{0}\right),
$$

where $\pi^{0}$ is a constant determining the intercept of the policy rule and $\alpha$ is a positive constant. Taking the unconditional mean, we have

$$
r-r^{*}=\alpha\left(\pi-\pi^{0}\right)
$$

First, consider the ad hoc aggregate demand relation (A3.2) and its unconditional mean, (A3.3). Combining it with the unconditional mean of the policy rule, (A3.7), gives

$$
u-u^{*}=\sigma \alpha\left(\pi-\pi^{0}\right)
$$

Using this with (A3.1) to eliminate the unemployment gap gives

$$
\pi-\pi^{e}=-\frac{\gamma \sigma \alpha}{1+\gamma \sigma \alpha}\left(\pi^{e}-\pi^{0}\right) .
$$

That is, if $\pi^{0}<\pi^{e}$ and $\pi^{e}=\pi^{*}$, we will have $\pi^{0}<\pi<\pi^{*}$ and by (A3.8) $u>u^{*}$. From (A3.3) we will have $r>r^{*}$. Thus, with the ad hoc aggregate-demand relation (A3.2), in a steady state with 
inflation expectations equal to the inflation target and inflation below the inflation target, the unemployment is higher than the natural rate and the real policy rate is higher than the neutral real policy rate.

Second, consider the New Keynesian aggregate-demand relation (A3.4) and the relation (A3.5) that follows from its conditional mean. From (A3.7) it follows that $\pi=\pi^{0}$. That is, if $\pi^{0}<\pi^{e}$ and $\pi^{e}=\pi^{*}$, we will have $\pi^{0}=\pi<\pi^{*}$ and $u>u^{*}$. Thus, with the New Keynesian aggregate-demand relation (A3.4), in a steady state with inflation below the inflation target, the unemployment is higher than the natural rate and the real policy rate equals the neutral policy rate.

For both alternative aggregate-demand relations, whether or not the steady-state equilibrium has inflation below target and unemployment above the natural rate is determined by whether or not the constant $\pi^{0}$ in the policy rule is below the inflation target.

\section{A4. The short-run NAIRU}

Assume the short-run Phillips curve (A2.1). We may define the short-run NAIRU, $\bar{u}_{t}$, as the unemployment rate that keeps inflation constant. From (A2.1), the change in inflation is given by

$$
\Delta \pi_{t} \equiv \pi_{t}-\pi_{t-1}=-\gamma_{1}\left(\Delta u_{t}-\Delta u_{t-1}\right)-\gamma \Delta u_{t-1}+\Delta \varepsilon_{t},
$$

where $\Delta$ denotes the first-difference operator. It follows that the short-run NAIRU will satisfy

$$
0 \equiv-\gamma_{1}\left(\bar{u}_{t}-u_{t-1}-\Delta u_{t-1}\right)-\gamma \Delta u_{t-1}+\Delta \varepsilon_{t},
$$

that is,

$$
\bar{u}_{t} \equiv u_{t-1}+\left(1-\frac{\gamma}{\gamma_{1}}\right) \Delta u_{t-1}+\frac{1}{\gamma_{1}} \Delta \varepsilon_{t} .
$$

The short-run NAIRU depends on two lags of unemployment and the change in the shock.

Given the form of the Phillips curve (A2.1), in particular that it is a "level" curve and not an "acceleration" curve (the coefficients on lagged inflation do not sum to unity; they are even zero), for zero shocks, any unemployment rate that remains constant over three quarters (that is, satisfies $u_{t}=u_{t-1}=u_{t-2}$ ) is a short-run NAIRU and satisfies (A4.3).

\section{A5. Inflation expectations depending on the unemployment rate}

A possible source of correlation between unemployment and the error term might be inflation expectations depending on unemployment. In (1), if inflation expectations $\pi_{t}^{e}$ were to depend on unemployment $u_{t}$, the error term $\varepsilon_{t}$ in (7) would be correlated with $u_{t}$. However, an OLS regression of inflation expectations shows that inflation expectations do not depend on unemployment. As seen in table A1, the coefficient on unemployment is very small and not significant. Even if it were to be significant, the coefficient is so small that it would not matter for the results in the paper. 
Table A1. Regression of one-year- ahead inflation expectations on annual CPI inflation and unemployment, 1996Q2-2011Q4

\begin{tabular}{cccc} 
Variable & Coefficient & Std. Error & Prob. \\
\hline Constant & 1.044 & 0.252 & 0.0001 \\
$\pi_{t-1}^{e}$ & 0.530 & 0.133 & 0.0002 \\
$\pi_{t-1}$ & 0.421 & 0.062 & 0.0000 \\
$\pi_{t-2}$ & -0.320 & 0.055 & 0.0000 \\
$u_{t}$ & -0.037 & 0.023 & 0.1099
\end{tabular}

Note: OLS, $\mathrm{R}^{2}=0.84$, adjusted $\mathrm{R}^{2}=0.83$, S.E. of regression $=0.23$, Durbin-Watson $=1.77$ 